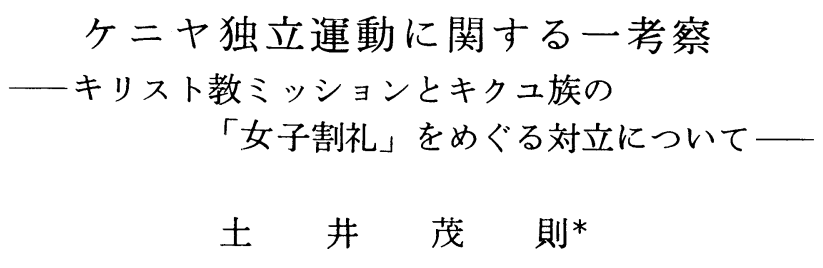

\title{
A Study of Kenya's Independent Movement
}

A case of the conflict on the girl's circumcision between Kikuyu and the Christian Missionaries

Shigenori Doi

Republic of Kenya achieved independence from England in 1963. But it is well known that the process of her independence was not so easy. There were so many conflicts against British colonial rule in Kenya. Mau Mau revolt was the largest and most intensive uprising in Kenya independent movement. Several reasons of this uprising already have been said by writers, historians, politicians and Mau Mau survivers. But even now no fixed theory to interpret Mau Mau revolt is appeared. It is obvious that Mau Mau revolt was the fight for Kikuyu land and freedom of Kikuyu people by Kikuyu people. The problem is that Mau Mau revolt included the phase of independent movement of nationalist, or not. Because most people who took part in this uprising were almost Kikuyu people, above all young Kikuyu people who had no land to cultivate. In this respect Mau Mau revolt was regarded as civil war between "haves" and "have-nots" in Kikuyu land.

Kikuyu Central Association in 1920s and Kenya African Union in 1940s were leading organization of political movement in Kenya. These organizations were led by more or less "haves" who were educated in the school of the Christian Missionaries. They were not always against British colonial rule and their purpose was wealth and political power in colonial system. Their movements were improvement of life to accept European life style and European civilization. Mau Mau revolt was different from these movement. Because most of people who took part in Mau Mau uprising were young and had not education of Christian Missionaries. In this point Mau Mau revolt was anti-European Christian civilization movement to keep identity of African.

In the beginning of 1900s Christian Missionaries came to Kikuyu land. They established Christian Missionaries schools. In 1910s they want to suspend the custom of girl's circumcision in Kikuyu land. Some of the Christian Missionaries decided to compel Kikuyu people give up the custom of girl's circumcision in 1920s. But Kikuyu people repulsed these policies of Christian Missionaries. As a matter of course, anti-Christian Missionaries movement was increased in violence in Kikuyu land. Kikuyu people denied to educate their children in schools of Christian Missionaries. They established their own schools and churches, which were Kikuyu Independent School to educate their children and Kikuyu Karinga School to educate Kikuyu traditional religion apart from Christian Missionaries.

*日本アフリカ学会会員 
The conflict between Kikuyu and Christian Missionaries in Kikuyu land had given influence on the independent political movement, especially later Mau Mau movement. In fact there are several reasons of Mau Mau revolt under British rule, which is labour policy, land policy and so on. The conflict between Kikuyu and Christian Missionaries was also one of the most important impact on Kikuyu Nationalism Movement.

\section{序}

ケニヤ共和国は 1963 年イギリスの植民地支配 から脱して独立したが，それに至る過程には，ヶ ニア国内のさまざまな部族による多くの独立運動 があった。

1952 年から 1956 年まで続いた，いわゆる「マ ウマウの反乱」は，その最も先鋭的な形で起った ものである。「マウマウの反乱」の中心はキクュ 族であるが，キクユ族は 1895 年以来のイギリス 植民地統治の最大の被害者だっただけに，その反 英運動は長く, 他の部族がさまざまな形で武力鎮 圧を受けた後も先鋭的に続いていたことは周知の 事実である。

特に, 1920 年代以降は, ケニヤに移住したヨ 一ロッパ人とキクユ族が，キクュ族の居住地であ るハイランド一帯をめぐり政治的に鋭く対立する. ハイランドの一部を白人専用地区（ホワイトハイ ランド）としてキクユ族を排除しょうとした為で ある。「ホワイトハイランド構想」は, 終局的に 「白人国家構想」に至るもので，ヨーロッパ人移 住者達はケニヤを将来,「第 2 の南アフリカ」に することを目論んでいた。これが，ケニヤの反英 運動を先鋭化させる最大の要因となる. 後の「マ ウマウの反乱」の際に参加者が行っていた「マウ マウの宣誓」が「土地奪還の為に戦う」という内 容をもっていたことからもわかるように「土地問 題」は反英の主要テーマであった。

その一方で, キクユ族とヨーロッパ人との文化 的対立が表面化する．キクユ族の部族慣習である

「女子割礼」をキリスト教ミッションがやめさせ ようとして，キクユ族と深刻に対立したのである. キクユ族の伝統的文化とキリスト教というョーロ ッパ文化とが真向から対立する文化闘争といって もいいであろうし，ある面では宗教的対立をも包
含するといってもよいであろう。こうした文化闘 争は，キク工族の広い範囲の支持を得て，反英反 ヨーロッパ文化感情が盛り上り，1920年代と 30 年代のキクユ反英運動の中心的政治団体である $\ulcorner\mathrm{K} \cdot \mathrm{C} \cdot \mathrm{A}(\mathrm{Kikuyu} \cdot \mathrm{Central} \cdot$ Association)」の 勢力を著しく強めるという結果が招来する.

「女子割礼」をめぐるキクユ族とキリスト教ミ ッションの対立は, その後のキクュ族の反英運動 に大きな影響を及ぼしている。そのひとつは，キ クユ族の伝統的部族慣習を擁護し, 宗教や教育を アフリカ人の手で行おうとする動きを顕著にした こと，もうひとつは，「 $\mathrm{K} \cdot \mathrm{C} \cdot \mathrm{A}\lrcorner$ の性格を変質 させたことである.

$\ulcorner\mathrm{K} \cdot \mathrm{C} \cdot \mathrm{A}\lrcorner$ は，ケニヤでもっとも早くキリ スト教ミッションの教育を受けたキクユの若者 達が中心になって作った団体で, その主要な目 標は，イギリス植民地体制の枠内で合法的にキ クユ族の利益を守ることであった。従って，

$\ulcorner\mathrm{K} \cdot \mathrm{C} \cdot \mathrm{A}\lrcorner$ そものは決してラディカルな ものとはいえず，大衆的政治基盤をもっていた ともいえない政治団体であった。しかし，キリス 卜教ミッションとの対立が表面化して以来, キク ユの大衆的支持を獲得するとともにラディカルに なっていった。このラディカルな部分が， 1950 年代の「マウマウの反乱」へと結びついていくの である。

その意味で，「女子割礼」をめぐるキクユ族と キリスト教ミッションとの対立は，キクユ族の反 英独立運動をみる上で看過できない重要な問題で ある。

ケニヤの独立運動の歴史をみると, きわめて明 白な特徵をもつ 3 つの時代に区別できる. 第 1 期 は，イギリスの植民地統治がはじまる 1895 年か ら 1920 年まで.この時代は，イギリスの行政機 構整備に対する各部族の武力抵抗が各地で瀕発す 
る・イギリスは，これに対して軍事的制圧を加え 大規模な討伐隊を派遺する。第 2 期は，1921 年 から 1945 年まで. 第 1 次大戦が終了した後 1920 年に東アフリカ保護領はイギリス領ケニヤとなる。 第 2 次大戦が終了するまでのこの時代は，ヨーロ ッパ型の大衆動員, 集会, 言論による組織的政治 活動が発生する. 更にこの時期から超部族的反英 独立を指向する動きが少しうつ現われる．第 3 期 は, 第 2 次大戦終了後 1946 年から独立までの期 間である。いうまでもなく，「マウマウの反乱」 というイギリス植民地統治史上最大規模のひとつ に数えられる武装闘争によって代表される。そし て, これらの各転換期に第 1 次, 第 2 次大戦があ る. 第 1 次, 第 2 次の両大戦には, 主要戦場が遠 く離れたヨーロッパやアジアであったのにもかか わらず, 多くのアフリカ人が動員されている. 彼 らが戦時中身につけた知識・経験が新しい政治活 動の組織化に大きな役割を果たしたのである。

キクユ族の反英独立闘争の総決算ともいうべき 「マウマウの反乱」の源流は，1920年代の反英 闘争にあるといってよいであろう。その中でも，

「土地問題」，「キリスト教ミッションとの女子割 礼をめぐる対立」、「強制労働などの労働問題」は, 反英感情を高め部族的団結を強化するのに直接の 影響を与えている。

1920 年代以降のキクュ族の反英運動の流れを みると，大きく 2 つの流れがある。

ひとつは，ヨーロッパ人の知識や生活様式を吸 収することによってヨーロッパ的近代化を受け入 れ，彼らと対等になろうとする人々の動きである. キリスト教の受容とヨーロッパ文明の吸収を内容 とする。この流れは，ケニヤでもっとも早くキリ スト教ミッションの教育を受けた人々によって形 成されたが，必ずしも反英独立を目標とはせず， イギリス植民地統治の枠組のなかで，合法的な権 利獲得運動をすすめた，1920年代に結成された キクュの政治団体 $\ulcorner\mathrm{K} \cdot \mathrm{C} \cdot \mathrm{A}\lrcorner$ 第 2 次大戦後に 結成された超部族的政治団体 $\ulcorner\mathrm{K} \cdot \mathrm{A} \cdot \mathrm{U}($ Kenya - African・Union )」もこうした流れに属する 人々によって組織されたものである.従って, キクユ族のなかの一部有識者, 富裕層の団体であ
って，当初は必ずしも大衆的支持を受けたものと はいえなかった。

他の流れは, アフリカ人の伝統的部族社会を基 盤にして，その伝統的生活を保持しながら，反英 ・反ヨーロッパ文明を運動の主要な目的とする動 きである、ヨーロッパ的教育，特にキリス卜教ミ ッション教育の拒否とアフリカ人の独自性の強調 を主な内容としている，彼らは，イギリス植民地 統治の被害をまともに受けた人々によって支持さ れ，ょり強い反ヨーロッパ感情に支配されていた 零細な貧しいキクユの人々に浸透していった。「K ・C・A」の下部活動家の多くは，この流れに属 していた.「マウマウの反乱」の活動家達もこの 流れから生まれてきている。

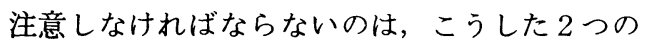
流れの分水嶺に当るのがキリスト教であったとい う点である。キリスト教を受け入れるかどうか， キリスト教ミッションの教育を受けるかどうかが， ヨーロッパ人社会で認められるかどうかの試金石 となっていた。キリスト教ミッションにとって， 布教に最も有利な状況を作り出すことは必要不可 欠であったから，キリスト教に理解を示す者，あ るいはキリスト教的教養・教育を身につけた者が ある国の指導者になり，エリート層を形成してく れることが望ましいのである，従って，アフリカ 人の教育を支配するか，強い影響力を及ぼしうる ならば，その望しい状況を作り出すことができる. こうした，キリスト教ミッションの教育支配を目 ざす動きに対して，アフリカ人は自らの手によ る教育を要求しはじめていた。キクュ族に関して は，「女子割礼」をめぐるキリスト教ミッション との対立が表面化して以来, 独自宗教, 独自教育 の動きが一層顕著になった。

本稿では，こうしたキクユ族の反英運動に強い インパクトを与えた「女子割礼」をめぐるキリス ト教ミッションとの対立問題に焦点をあてること で「マウマウの反乱」に至るケニヤの独立運動の 一側面を考えてみたいのである。 


\section{1920 年までの反英抵抗運動}

ケニヤの 67 年間のイギリス支配のなかで，反 英運動を担って来たのは，けっしてキクュ族のみ ではなかった，各地域の各部族がさまざまな形で 抵抗を行っていたのはいうまでもない。「マウマ ウの反乱」という形で生じたキクユ族の武装闘争 が，あまりにも強烈で，しかもケニヤの独立に直 接的衝撃を与えたと考えられているだけに，他の 部族の反英抵抗運動が没却されるきらいがある.

イギリスの植民地統治は, 既存の政治権力を利 用する間接統治方式で行われていた. 東アフリカ の大多数の部族は, ビクトリア湖周辺の一部の部 族を除いては，集権的支配構造をもたない，集団 指導的部族運営が行われていた。このことが，イ ギリスに「有力な支配者がいない」という認識を 生ぜしめ,「チーフ制度」(Muriuki, 1974, pp. 136-166) の導入という形をとって行政権の確 立がはかられていた。「チーフ制度」とは植民地 行政の末端行政官をアフリカ人に担当させる制度 である，伝統的部族社会構造を無視した形の「チ 一フ制度」の導入は, 各部族社会を混乱させ, 更 に「チーフ」に任命される者が，伝統的秩序から は受け入れられない者, 例えば東アフリカ会社に 雇われていたポーター，アスカリ（兵士），ガイ ド等々であって，彼ら自身が部族社会から受け入 れられず，混乱に拍車をかけた。「チーフ」の主 要な仕事は, アフリカ人労働力の確保の為に労働 者をあつめること, 治安維持, 後には税の徵収を も含まれた。彼らはきわめて乱暴な形でアフリカ 人を強制的に徵発してヨーロッパ人農場に送り込 んだり，税収入をごまかし，私的目的で私兵を動 かし伀統的部族社会の秩序を破壊した。そして， みずからの権力と私財を確保する為に略奪暴行は 日常的でさえあった. 当時の「チーフ」達の行動 は，奴隷制度のあった時代よりひどかったとさえ いわれている(Ogoto, 1968，p.266). しかし，

「チーフ」は植民地統治の新しい権力者として， 伝統的部族社会の反感を買いながらも，財産を蓄 積し，またたく間に新興勢力に成長している.

アフリカ人の反英抵抗は，こうした末端行政官
である「チーフ」に対する反抗を通じてはじまっ ている．植民地統治の新しい行政権確立に伴う伝 統的部族社会との対立が大きくなり「チーフ」と その私兵のみでは治安維持が困難になると, イギ リスは討伐部隊を派遺して抵抗を排除した。

1920 年までの主な討伐部隊の派遺があったの は次のようである。

ケニヤ・コースト地方の住民が，イギリスとオ マーン・アラブのスルタンとの間にとりかわした コースト地方の支配権移譲条約に反発して反乱を おこした「マズルイの反乱」(1895年1月）。ウ ガンダ鉄道建設に抵抗し続けたナンディ族に対す る討伐は，1901年，1904 年，1905年に大規模 に行われた。 エンブ族，グシイ族に対する討伐は 1904 年. 1905 年には，エンブ族，キプシギス族 に対し, 更に 1907 年にはバクス族, カブラス族, 1908 年には再びグシイ族に対して討伐が行われ ている.

こうした討伐隊の派遺は，それまで部族戦争と いえば弓矢, 槍, 刀による小規模な家畜争奪戦で, 死傷者も数人で終っていた従来の戦争観を一変さ せ, 大量の銃器による数十人, 数百人の死傷者を 出すものに変った。無差別にも近い無意味な殺瀻 に，抵抗が制圧された後の人々の反発も一段と増 していった.

1910 年代に入ると, 圧倒的軍事力の前に武力 抵抗が鎮圧され，アフリカ人の抵抗運動は多様な 形をとるようになった．不服従運動や宗教的色彩 を帯びた精神的反英運動である．注目すべきもの は, カンバ族の「踊り」による反英運動（ibid, p. 263 )，ルオ族，ルヒヤ族，グシイ族などの住 むビクトリア湖東岸のニャンザ地方で発生した「ム ンボイズム ( Mumboism)」運動 (Ogoto, 1968, p.263 ; 1968, pp.149-178; Ogoto and Ochieng, 1972，p.147), 直接の反英運動とはいえないが, アフリカ人独自の宗教運動の最初のものである, ジョン・オワロ (John Owaro) の「ザ・ノミア・ル オ・ミッション ( The Nomia Luo Mission) ( Ogoto, 1968, p.262) であろう.

カンバ族の「ンガイ・ンゴマ( Ngai ngoma)」 運動は，1911 年頃にマチャコスやキッイで始ま 
った.「クルミ(Kulumi)」と呼ばれる伝統的 部族ダンス（悪霊追払の目的）を反英運動の手段 として利用したものである. 保護領政府やヨーロ ッパ人のポーターにならない, 税の支払を拒否す る，ヨーロッパ人をケニヤから追放する，等々を 祈禱して踊り，カンバ族の人々の間に浸透してい った。1913年にイギリスは, 軍隊を派遺して「ン ガイ・ンゴマ運動」を弾圧し, カンバ族の部族ダ ンスを禁止した。

一方，ビクトリア湖周辺で広がった「ムン ボイズム運動」きわめて広範囲かつ根強い反 英反ヨーロッパ運動となっていた。「ムンボ ( Mumbo)」とは，「太陽と湖の神」で反キ リスト教, 反ヨーロッパ人を主張する独特の宗 教的色彩の強い運動である.オニャンゴ・ドゥン デ ( Onyango Dunde) という人物によってはじ められた「ムンボイズム運動」は，すぐにニャン ザ地方全域に広がり，部族を超えて支持を得た。

「ムンボイズム」は，「キリス卜教は腐っている. その役割は信者に服を着せることだ，我々は，髮 を切ることなく伸ばし, 着るものは羊や家畜の皮 でなければならない.けっして洗ってはいけない. すべてのヨーロッパ人は敵である. 彼らが我々の 土地から姿を消す日が遠からず来るであろう。」

(Ogoto and Ochieng, 1972, p.148) と主張す る.「ムンボイズム」は1919年に弾圧を受け, 主要なリーダー達が逮捕されたが，この運動は 1940 年頃まで続いた。

1914 年には，コースト地方のギリヤマ族が武 装反乱をおこしイギリスの地方拠点を攻撃したが, 1915 年に鎮圧された ( Temu, 1972, pp.215$236)$.

このように植民地統治のための行政組織の確立 は軍事力の背景なくしては決してあり得ず, 討伐 隊の派遺に伴う軍事費の増大は, イギリスの財政 負担を增大させ，東アフリカ保護領の経済開発を 促す一因となった。

1914 年にはじまった第 1 次世界大戦は, 東ア フリカにも直接に影響を与えている.イギリス軍 とドイッ軍が戦闘を交え, 多くのアフリカ人が東 アフリカの戦闘に動員された。ケニヤだけでも 1 万
人以上の兵士と 19 万 5 千人の軍事労働者が戦場 に狩り出され, 家畜や食糧が供出された上に, 戦 時経済をまかなうため増税さえ行われている。そ して，5万人以上の者が死亡したとされているが， その死亡率は $25 \%$ 以上という驚くべき高さであ った。彼らがいかに苛酷なあつかいを受けていた かを物語るものである。しかし,この戦争で経験 したことは，アフリカ人にヨーロッパ人と対等で あるという自信を呼びもどし，1920年代の新し い政治運動の原動力となる. 新しい, 政治指導者 のほとんどが, 東アフリカ戦線に従軍した経験を もっていたことが，このことを証明している(Ogoto， 1968$, p. 264$) .30$ 年後の「マウマウの反乱」を 含めた 1940 年代, 50 年代の反英独立運動におい ても，これとまったく同じ様に第 2 次大戦でョー ロッパ, 北アフリカ, ビルマの各戦線に動員され た若者が，新しい政治運動を展開していったこと は注目すべき現紘であろう。

\section{2.「マウマウの反乱」1)}

1945 年, 第 2 次大戦が終ると各地に動員され ていたアフリカ人がケニヤに復員して来た. 彼ら は, ヨーロッパ, 北アフリカ, ビルマで戦闘経験 を積み, 組織力の重要性に気付き, 民族的自覚を もって帰った (Itote, 1967, pp.1-30).1947年 頃には，こうした若者がケニヤの現状変革を目ざ して各地で行動をおこしていた.キクユ族内にも 彼らの運動集団がさまざまな形で存在している. 1940 年に割礼を受けたキクユの若者達は，「40 年組 ( Anake a 40$)^{2)}$ と呼ばれるグループを結 成して反英運動を行っている.ナイロビなどの都 市では, 労働者, 失業者, 復員兵士が労働組合運 動や大衆運動に参加していた。これらの諸々の運 動体やグループの中から「マウマウの宣誓」と呼 ばれる宣誓を行った者が武装蜂起に向っていき「ケ ニヤ自由軍 (Kenya Land and Freedom Army )」（マウマウ団）を結成するのである.

「マウマウの宣誓」とは，1920年頃からキク ユ族の内部で広がっていった「宣誓」で, (1) ヨー ロッパ人に土地を譲り渡さない. (2)奪われた土地 
は取り返すといった内容をもつ「「宣誓」その ものは, キクユ族の伝統的部族慣習の中にある形 式で行われていて, 特別のものではなかった。こ うした「宣誓」を行った者のなかから更に将来武 装蜂起するときに参加する決意をもつ者を選抜し て, (1)土地奪還の為に戦う, (2)仲間を裏切らない, といった内容の宣誓を行わせた。この「宣誓」も キクユ族が部族戦争を開始するときに「戦士」達 が行う「戦いの誓」と同じもので特殊なものでは なかった。しかし、 ヨーロッパ人には，これらの 「宣誓」が何か秘密宗教の活動と受けとられてい たようであるが，その実態は，キクユ族に伝統的 に伝わる慣習であった．第 2 次大戦後，「マウマ ウの宣誓」がキクユ族の居住区域全部に広が り, ナイロビでも行われるようになると, 植民 地政府は, 積極的に取締り, 集会を禁じ, 指 導者を逮捕した。当時, ケニヤで政治活動を 認められていたのは， K・A・Uだけであった。 この政治団体は, 1945 年にケニヤ立法議会に はじめてアフリカ人議席が割当てられたこと で，アフリカ人議員をバックアップする為に組 織された超部族的団体である.アフリカ人利益 の擁護とアフリカ人議席の増加を当面の活動方針 としていて，メンバーは植民地体制のなかで合法 的に権利獲得をめざす一部有識者（キリスト教ミ ッションスクールの教育を受けた者 ), 部族代表 者, 有産者などであった。1946年にジョモ・ケ ニヤッタ（ケニヤ初代大統領）がイギリスから帰 国して, $\mathrm{K} ・ \mathrm{~A} \cdot \mathrm{U}$ 委員長に就任し, $\mathrm{K} \cdot \mathrm{A} \cdot \mathrm{U}$ の メンバー資格を労働組合員や一般大衆にも開放し た結果， $\mathrm{K} ・ \mathrm{~A} \cdot \mathrm{U} は 大$ 衆政治団体に変わった。こ のとき, 後の「マウマウ団」の中心メンバー達は, 自分達の非合法活動をカモフラージュする為に， 合法政党である $\mathrm{K} \cdot \mathrm{A} ・ \mathrm{U}$ に大量に参加した。この 為, $\mathrm{K} \cdot \mathrm{A} ・ \mathrm{U} の$ 下部活動家は,「マウマウ団」の 活動家と同じになってしまい，彼らがほとんどキ クユ族であったことで，あたかも $\mathrm{K} ・ \mathrm{~A} ・ \mathrm{U}$ あ゙キク ユの政治団体であるかのような観を呈した．今日， 「マウマウ団」は， $\mathrm{K} ・ \mathrm{~A} \cdot \mathrm{U}$ の穏健派と武闘派の 分裂の結果とみる見方があるが，「マウマウ団」 の生存者はそれを否定している.つまり，一方に
$\mathrm{K} \cdot \mathrm{A} ・ \mathrm{U}$ という植民地政府の認める合法政党があ り, 他方に武装蜂起をめざすグループがあった. 武装蜂起をめざすグループは, 非合法で治安当局 の目をのがれるために $\mathrm{K} ・ \mathrm{~A} ・ \mathrm{U}$ に積極的にもぐり

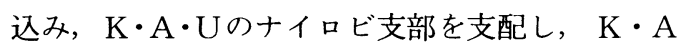
-Uの中央委員会に 2 名の中央委員を送り込んだ のである ( Kagia, 1971，pp.108-114)。しかし， イギリス治安当局は，「マウマウ団」は，K・A ・Uの秘密軍事組織とみていて, ジョモ・ケニヤ ッタをはじめとする $\mathrm{K} ・ \mathrm{~A} ・ \mathrm{U}$ の指導者・主要メン バーは「マウマウ団」とは無縁であったにもかか わらず，1952年10月の「非常事態宣言」と同時 に全員が逮捕されることになる.

1951 年, $\mathrm{K} ・ \mathrm{~A} ・ \mathrm{U}$ はケニヤの実情をイギリス 本国政府や国連に訴えるためヨーロッパやアメリ カに代表団を派遺した. $\mathrm{K} ・ \mathrm{~A} ・ \mathrm{U}$ の指導的メンバ 一達は，この代表団に現状打開の期待をかけたが 成果はなかった， $\mathrm{K} ・ \mathrm{~A} ・ \mathrm{U}$ 内の「マウマウ団」の メンバーは，この代表団が失敗すれば決定的行動 をとることを確認して武装蜂起の準備に入った. 彼らは, 秘かに「戦争指導会議」を設置, ケニヤ 山 (5200メートル) やアバデア山 (4000メートル) の森林地帯にゲリラ戦のための根拠地作りと武器 の収集を開始した。この「戦争指導会議」は, キ クユ族の伝統的部族慣習に範ったもので部族戦争 が開始されるときに戦闘指導を目的として置かれ るものである。「マウマウ団」は武装蜂起を開始 するにあたり，戦闘区域を大きく 3 つに分け，そ れぞれに独立した戦闘指揮権を与えた。ケニヤ山 地区（リーダー：ワルヒウ・イトテ），アバデア 山地区 ( リーダー : スタンレー・マセンゲ, 後に デダン・キマチ)，ナイロビ地区(十イロビ中央 委員会) がそれである. 各地区の戦術調整と補給, 情報収集はナイロビ中央委員会が担当し, 森のゲ リラ戦については, 各リーダーの責任にまかされ ることにされていた。

1952年 10 月 7 日, ナイロビ郊外で 1 人のアフ リカ人行政官 (チーフ・ワルヒウ ) が暗殺された. この事件をきっかけに 10 月 20 日，ケニヤ中央部 に「非常事態宣言」が布告された. 同時に, 一切 の政治活動が禁止され, $\mathrm{K} ・ \mathrm{~A} ・ \mathrm{U}$ の指導メンバー 
183名が逮捕された。そして，イギリス軍歩兵 2 個大隊がカイロから到着して，頻発するテロ活動 に対処すべく，白人農場や都市警備にあたる。 1953 年は,「マウマウ団」の活動がもっとも盛 んになる年で, 各地の警察署, 政府軍駐屯地, ア フリカ人行政官の家が襲撃された. 1953年3月 26 日のナイバシャ警察署の襲撃は「マウマウ団」の 力を誇示すると同時に大量の武器弾薬を奪って武 装強化に貢献した。同じ 3 月 26 日, ナイロビ郊外 の「ラリ」という小さな村で「ラリの虐殺」と呼 ばれる村民皆殺し事件が発生している．植民地政 府はこれを「マウマウ団」の仕業と発表している が，「マウマウ団」生存者はそれを否定し，植民 地政府治安部隊が「マウマウ団」の野蛮さ狂暴さ を宣伝するために仕組んだ事件だといっている (Wachanga, 1975, pp.14-15). 3 月の「ナイ バシヤ警察署襲撃」以来,「マウマウ団 (ケニヤ 自由軍 )」の攻勢は 1953 年末まで続いた。ケニ ヤの警察力は，1951年に約 6 千人であったが 1954 年には約 1 万 2 千人と 2 倍に増強されている. 当 初，植民地政府は警察力だけで充分鎮圧できると 考えたようであるが，1953年の中央州全域の組 織的攻勢をみて事態が予想以上に深刻なことを知 り，イギリス正規軍による本格的鎮圧作戦を要請 せざるを得なくなる。1954年 4 月，カイロの中 東軍司令部よりアースキン少将がナイロビに到着し て, 本格的鎮圧作戦準備と部隊編成にとりかかっ た.?）本国からの増援を含めて同年 9 月に編成を 完了寸る. 総兵力は約 1 万で, 次のような編成で あった。

イギリス正規軍 2 個連隊 (約 3 千名 )

$\mathrm{K} \cdot \mathrm{A} \cdot \mathrm{R}$ ( Kings African Rifle 連隊)：1個 連隊 (約 3 千名)，ケ二ヤ連隊，計 4 個連隊（約 8 千名 ), 戦車 1 個大隊, 砲兵 1 個中隊, 飛行 2 個中隊 (戦爆機 9 , 爆撃機 6 )

1953 年 6 月から 12 月にかけ大きな戦闘が 2 回 〜 3 回発生している.しかし, 1954 年に入ると 政府軍の反撃が開始される。1954 年はじめ, 植 民地政府は，「マウマウ団（ケニヤ自由軍）」と の間に和平交渉をもっている。これは，その年の 1 月に負傷して捕まったケニヤ山地区のゲリラ戦
のリーダーであるワルヒウ・イトテが仲介したも のであった（Itote, 1967, pp.1-30)。和平交渉 そのものは, 予備交渉段階で突発的戦闘が発生し て決裂する。この時,「マウマウ団」は, 和平交 渉支持派（スタンレー・マセング派）と戦闘続行 派（デダン・キマチ派）に分裂し，交涉決裂と同 時に和平交涉支持派が戦線を離脱する事態がおこ る。

一方, 政府軍側は和平交渉の停戦期間を利用し てキクユ自警団（Kikuyu homegard）を再編強 化する．和平交涉は政府側にのみ有利に作用し た。

和平交涉が決裂するとアースキン少将は，ナイ ロビの「マウマウ」を一掃する「アンビル作戦」 を開始した。4 月 2 日，軍・警察を総動員してナ イロビを包囲，各アフリカ人居住区を一斉に捜 索，キクユ族，エンブ族，メルー族を中心に検 挙して強制収容所に送り込んだ。この作戦のた め新たに 10 数力所の収容所が新設され，逮捕 者は 3 万人に達した。「アンビル作戦」の結果, ナイロビの「マウマウ」の中央組織である「ナイ ロビ中央委員会」は潰滅した。こうした都市での 掃討作戦はその後も各地で行われ都市の治安回復 に成功する．1954 年後半に入ると，アースキン 少将は, 森林地帯でゲリラ戦を展開している「マ ウマウ」を住民と分離し森の中に封じ込める作戦 をはじめた。キクユ居住区に「要塞村」を新たに 作り，キクユの住民をその中に移住させゲリラと の接触を断ち，彼らを孤立させるというものであ る.村のまわりに堀を作り，有刺鉄線でかこって 自警団を配置する。こうした「要塞村」の建設は 急ピッチですすめられ 1954 年末までにほぼ完成 した. 正確な数は不明であるけれども約 100 万人 が強制移住されたともいう。その結果，森の中の 「マウマウ」は完全に孤立し, 食糧・武器弾薬の 補給は杜絶した。ただでさえ苦しい森の生活は一 層困難になった。食糧を求めてキクユ居住区に入 り射殺される者が増加する。

第 1 , 第 2 段階の作戦を順調に完了したアース キン少将は第 3 段階の作戦にとりかかった。「マ ウマウ」を完全に森の中に封じ込め, 山頂から討 
伐部隊を山麓に向って移動させ森の中の根拠地を 吒き，基地を失ってキクユ居住区に接近して来る 残存ゲリラを包囲撃滅するという作戦であった。 1955 年 1 月から「ハンマー作戦」と名付けられ た作戦が開始され，アバデア山中に討伐部隊が送 り込まれた。作戦期間中の必要物資は航空機から パラシュート投下されて，約 2 週間続いた。しか し，「マウマウ」のゲリラ部隊と遭遇することが 少く, 大掛りな作戦の割に成果はなかった。ケニ ヤ山地区でも同様の作戦が 2 回ばかり行われたが, 成果はなかった。.以上のような本格的討伐作戦が 意外に成果に乏しいことがわかると，軍事費用の うえからも批判が多くなり作戦は変更された。今 までの大部隊投入を止め，小部隊を森の中に分散 配置して「マウマウ」のゲリラ部隊との遭遇をま つという作戦に切りかえられた。しかも，その小 部隊は，投降した「マウマウ」戦闘員から編成さ れた。彼らの目標は，アバデア山地区で最後まで 抵抗を続けているゲリラのリーダー，デダン・キ マチを逮捕することにあった。デダン・キマチは 少数の戦闘員とともに行動していて, 森の中で待 ち伏せ攻撃を狙う政府軍コマンドを警戒して旧来 の根拠地を避けていた。キマチのグループと政府 軍コマンドとの接触は 2 回ばかり発生した。1 回 目のとき，待ち伏攻撃を受けてキマチのグループ は各自散り散りになり, キマチはその後単独行動 をとっている，2回目のときは，森の中を移動中， 不意の銃撃を受け 3 日 3 晚 $80 \mathrm{~km}$ も逃げた. 1956 年 10 月 20 日, キマチが食糧を求めてキクユ部落 に近づいたときキクユ自警団に発見され，銃撃を 受け負傷・逮捕された。

デダン・キマチの逮捕により「マウマウの反乱」 も実質的に終了した。「非常事態宣言」が布告さ れて四年目のことである。「非常事態宣言」その ものは 1960 年まで続き「マウマウ」の活動も， ケニヤが独立する 1963年 12 月まで止まなかった が，実質的影響はなかった。デダン・キマチは， その後裁判によって死刑を宣告され，4ケ月後ナ イロビで処刑され，29才で生涯を終えた。

「マウマウの反乱」の損害は次のようである.

「マウマウ団（ケニヤ自由軍）」側戦死者 1 万
1503 名，負傷者 1053 名，捕虜1550名，逮捕者 2 万 6625 名, 降服 2714 名, 計 4 万 3427 名.

イギリス側戦死者 2044 名 (白人 95名, アジア 人 29 名, アフリカ人 1920 名)，負傷者 4604 名 (白人 127 名, アジア人 48 名，アフリカ人 2385 名 ), 合計 4604 名 (白人死傷者 222 名, アフリ 力人死傷者 4305 名, アジア人死傷者 77 名 ).

双方の死傷者合計は 1 万 7142 名で, この他に 約 7 万 7 千人以上が強制収容所に収容された。

以上が「マウマウ団の反乱」と呼ばれる，ヶ二 ヤ反英武装闘争の概略である。「マウマウの反乱」 をケニヤ独立運動史上どう評価すべきかについて 現在まで定説はない。ことにアフリカ人歴史家に よる学問的評価は皆無に等しい。ナイロビ大学を 中心に資料の収集・発堀・出版が精力的になされ ているにもかかわらず，アフリカ人研究者の多く は，現在の段階で学問的評価を下すことに慎重で ある．その理由は，資料が不充分であるというこ とに尽きる (Ogoto, 1968, p.288)．従って，現 在まで発表されている評価は，ヨーロッパ人，ア メリカ人研究者によるものが多い.

「マウマウの反乱」をどうみるかについて大別 寸れば 4 つの説に分けられる.

(1)「農民一揆」説，(2)「キクュ族の内戦 (階級 闘争 ）」説，(3)「宗教闘争」説，(4)「民族独立闘 争」説，等々である。

(1)「農民一揆」説は, 当時のヨーロッパ人や植 民地政府関倸者に一般的であった見方である．土 地を持たないキクユの若者達が，一部の野心的煽 動者に煽られて一揆的にテロに走ったという。こ の見方には，「マウマウの反乱」の原因は，社会 的政治的問題ではなくアフリカ人の心理的問題で あるとする見方が底流にあり，「マウマウ団」な るものは，「感覚的・感情的強迫観念にとりつか れた」狂信的幻想集団にしかすぎない，アフリカ 人が政治的社会的不満で武器をもって立ちあがる などとは考えられない，という強固な先入観又は 偏見に支配された見方である。

(2)「キクュ族の内戦 (階級闘争) 」説は，「マ ウマウの反乱」の主として植民地政府の側に立つ アフリカ人（ロイヤリスト）を攻擊の対象とした 
ことや, キクユの貧農層の若者が多数参加して, チーフ，土地所有者，富裕層を敵に回した「持て る者」と「持たざる者」の闘争であったとする見 方である(Ogoto，1968，p.288）。すでにみたよ うに「マウマウの反乱」に伴う死傷者数をみれば, ヨーロッパ人の死傷者は 222 名にしかすぎず， ア フリカ人の死傷者は「マウマウ」側 1 万 2556 名, イギリス側アフリカ人 4305 名とアフリカ人の死 傷者が圧倒的に多い。このことからみれば，「マ ウマウの反乱」はアフリカ人とアフリカ人の戦い であったといえ，その限りでは「キクユ族の内戦」 説も妥当である。また，「マウマウの反乱」後の 政治状況とケニヤ独立後のキクュ政権成立をみて も，“持てるキクユ"層のエリート化が実現して いることは事実であり，「マウマウの反乱」の階 級闘争的側面は否定できない。

(3)「宗教闘争」説は，「マウマウ団」は榣健な キクユ族をテロリズムに走らせた新興宗教団であ り「宣誓」という一種独特の宗教的儀式により 人々の精神を拘束して狂信的武装闘争を強制した， という見方である.この見方は, 当然のことなが らキリスト教関係者に支持されているし，キクュ

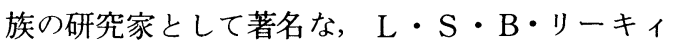
( Leakey, 1952, pp. 86-93) の説でもある. 政 治的社会的原因から「マウマウ反乱」を分析 するよりも，宗教的文化的側面に焦点をあて る見方である。1929年にさかのぼるキクユ族 とキリスト教ミッションとの対立が「マウマウ」 を理解する最も重要なポイントということにな る。

(4)「民族独立闘争」説は，「マウマウの反乱」 はヨーロッパ文明とキリスト教に対するアフリカ 人の民族運動であり，同時にイギリス植民地支配 に対する民族独立運動であったとする見方である. この説には多数のアフリカ人政治家、「マウマウ」 生存者 ${ }^{4)}$ が支持し賛同している。「マウマウ団」 は，その結成の当初から「反英独立」を目標にし ており, 主要なリーダー達の多くは第 2 次大戦に より各地に動員され, 戦闘経験や各国の実情を知 った。そこから民族的自覚と国家独立の展望を模 索していったのである(Itote, 1967, pp.1-30).
従って，「民族独立闘争」説が，「マウマウ」が 武装蜂起に至った目的にもっとも近く, 参加者の 意向にも沿っている．そして「マウマウの反乱」 終息後の代表的政治家である $\mathrm{J} \cdot \mathrm{M}$ ・カリウキ $(\text { Kariuki =キクュ出身 })^{5)}$ や T・ムボヤ $($ Tom Mboya =ルオ出身 $)^{6)}$ がこうした見方を支持して ケニヤ独立後, 必ずしも正当な評価を受けていな い「マウマウの反乱」の再評価を主張してきた.

「マウマウの反乱」は, 社会経済的観点からす れば，「キクユ族の階級闘争」説の指摘する面が あり，政治的観点からすれば「民族独立闘争」説 が強調されるべきであろう. 多数の部族をかかえた 国内事情からいって「民族独立闘争」説のみで説 明するには多少無理があると考えられる。タンザ ニアの「マジマジの反乱」にみられるような広範 な超部族性はもっていないところに「民族独立闘 争」説のみでは説明できない弱点をかかえている. 勿論，「マウマウの反乱」がキクユ族のみで戦わ れた訳でもなく少数ながら，マサイ族，カンバ族, ルオ族出身者が個人的に参加しており，「マウマ ウ」の指導部も各部族に参加を呼びかけ連絡をと ったが拒否され, 結果的にキクユ族中心の武装蜂 起にならざるを得なかった面もある以上，「民族 独立闘争」説を全面的に否定することもできない． イギリス側も各部族が「マウマウの反乱」に呼応 することをもっとも警戒し, 分断工作に苦心した ことが, 効を奏してキクュ族の単独武装蜂起に終 ったのである. 従って,「キクユ族の階級闘争」 説と「民族独立闘争」説を中心に考えていくのが 妥当であろう。

\section{3. キリスト教ミッションの「女子割礼」反対 の時代背景 ( 1920 年代 )}

キリスト教ミッションとキクユ族が「女子割礼」 をめぐって対立したのは 1929 年のことである. 1920 年代は, キクュ族が反英運動の中心的位置 を占めはじめ, 新しい政治運動形態が出現した時 代でもあった。

1920 年, 東アフリカ保護領はイギリス領ケニ ヤとして，コースト地方の10マイル地帯を除い 
てイギリス領に併合された。そしてイギリスは, ケニヤをいかなる形で統治すべきかを模索するた め各種の調査団を派遺した。これら調査団の報告 書は，ケニヤをヨーロッパ人，インド人，アフリ カ人の 3 人種融合国家にしていくことを提案し, インド人移民制限の撤廃，アフリカ人利益の優先 ( Parlimentary Paper, 1925, Cmd 2387 ). 東 アフリカ連邦化構想の時期尚早を報告している.

しかし，これらの報告書 ( Parlimentary Paper, 1929, Cmd 3234 )にヨーロッパ人移住者は反発 し，ヨーロッパ人利益の最優先を主張してイギリ ス本国政府に抵抗しょうとした。

ヨーロッパ人移住者, インド人, アフリカ人の 利害が対立する国内事情の下で，アフリカ人も自 分達の利益を守るため政治団体を結成していく. まず土地問題に関心をもつキクユ族のチーフ，へ ッドマン達が「キクユ連盟 (The Kikuyu Association)」を結成 (1920年) した.しかし、「キク ユ連盟」の植民地政府の意向に從順な姿勢に反発 したキクユの若者達が，「ヤング・キクユ連盟」 ( The Young Kikuyu Association)」 ${ }^{7)}$ を結 成した。 そして, 全ケニヤ的超部族的政治団体に するため約 1 ケ月後に「東アフリカ連盟 ( East Africa Association )」と改称して, 反K・A, 反政府的活動を開始した．指導者ハリー・ツクは 1922 年 3 月 14 日に「公共の秩序に危険なる人物」 として逮捕されるが，彼の逮捕に抗議するデモ隊 がナイロビ警察署前に座り込み, 警官隊がこれに 発砲して多数の死傷者を出した.8) この事件のあ と一切の政治活動・集会が禁止された. 2 年後に 植民地政府の超部族的政治団体は認めないが各部 族単位の政党ならば認めるという見解が公表され

「東アフリカ連盟」は「キクュ中央連盟 (Kikuyu Central Association) 」と改称して, 政治活動 を再開した。

一方, ケニヤ第 2 の多数部族であるルオ族と第 4 のルヒヤ族が中心となって「ヤング・カビロン ド連盟 (The Young Kavirondo Association)」 が結成され $^{9)}(1923$ 年) ビクトリア湖地方で活動 をはじめていた。

これら代表的アフリカ人政治団体の活動方針は,
メンバーの個人的教育改善を指向したもので，有 産者団体と考えられている。例えば， $\mathrm{K} ・ \mathrm{C} ・ \mathrm{~A} の$ 初期の活動は, 「チーフ」の任命, アフリカ人の 葬儀の格式, 住居の衛生検查, 最低限 1 地方 1 病 院の設置, 教育のための学校の設立, 等々の生活 改善問題に集中していて, 植民地主義や国内の差 別的政策をとりあげることはなかった， $\mathrm{K} ・ \mathrm{C} ・ \mathrm{~A}$ の機関誌「ムイグウィザニア( Muigwithania)」は 1928 年に発刊されるが，その初代編集長となっ たジョモ・ケニヤッタ（Jomo Kenyatta）のある 論説は次のようであった。

「もしキクュの人々が (エンブ族やメルー族も 含めて) 重要な部族になることを望むなら，ヨー ロッパ人のように勤勉で, 信頼され, 忍耐うよく, 幸福に, 協調的でなければならない。そうした教 養をみにつけるべきである。バガンダ族のような 部族は，農業に精を出し，子供達をヨーロッパに 留学させる．彼らが国に帰ると重要なポストを占 め，人々を啓発する、ヨーロッパでは人々はよく 教育を受けている.」(Ogoto, 1968, p.282 )

$\mathrm{K} \cdot \mathrm{C} \cdot \mathrm{A}$ 指導層の関心は， ヨーロッパ的教育・ 生活様式を身につけてヨーロッパ人と対等になろ うとすることにあった。この考え方は，今日のケ ニヤに重要な地位を占めるキクュ・エリートに受 けつがれている，その意味で， $\mathrm{K} ・ \mathrm{C} ・ \mathrm{~A}$ は当初か ら反英的政治団体であった訳ではなく，むしろ親 英的有産者集団であったといってよい（ibid）． 一般のアフリカ人にとって，こうした主張がいか に現実離れしたものであったかは容易に推察でき る. 彼らに対する植民地政策は苛酷以外の何物で もなかった．増税と賃金の引き下げ，キパンデシ ステム ( 身分証明書携帯義務) の導入, ${ }^{10}$ ) 強制労 働と低賃金労働の担い手としてしか位置づけられ ていないアフリカ人に対して苛酷な労働政策が打 ち出されている。アフリカ人を伝統的生産手段か ら切り離し、 ヨーロッパ人の生産活動に必要な低 貨金労働力として利用することが，ヨーロッパ人 を中心とするヶニヤ経済開発に不可欠とされてい たからである．1925年に K・C・Aは，アフリカ 人にもコーヒー栽培を認めるよう運動をはじめた が，これも土地所有者や有産者にとって重要なこ 
とであっても大多数のアフリカ人には関心のない

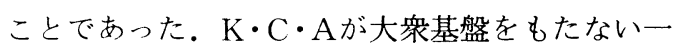
部有識者, 有産者の団体であったことは当初のメ ンバー及び活動方針が示すところである。1929 年の「女子割礼」をめぐってキクユ族とキリスト

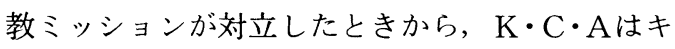
クユの大衆的支持を獲得し, 同時にラディカルな 運動体に変質した.

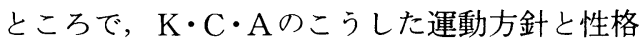
について，大きな影響を与えたのが，他でもない キリスト教ミッションであったという説がある ( Kikorir, Ph. D theses, 1969). K・C・Aの 当初の方針が，ヨーロッパ的教養, キリス卜教的 教養を身につけることによってヨーロッパ人と対 等になることにあったことはすでに述べたが，こ れはキリスト教ミッション教育の成果といってよ い. 1920 年代の新しい政治運動の担い手は, ケ ニヤでもっとも早くキリスト教ミッションの教育 を受け，第 1 次大戦に参加した若者達であった。 彼らはヨーロッパ人社会に完全に受容されること もなく，かといってアフリカ人の伝統的社会に戻 ることもできない状況の中で，植民地政府と伝統 的部族社会の双方に反発を感じていた。その頃, やはりヨーロッパ人と対立していたインド人社会 (Mangat, 1969, p.15) に彼らは接近して, アフ リカ人とインド人の協同関係を維持しょうと試み ている。アフリカ人とインド人の同盟関係の動き を積極的に阻害したのがキリスト教ミッションで あった。インド人は異教徒であり，キリスト教布 教の可能性は少い。もしアフリカ人とインド人の 同盟関係が成立してインド人がその指導権を握れ ば，アフリカ人にとってもキリスト教ミッション にとっても好ましいことではない.キリスト教ミ ッションは, アフリカ人に将来インド人と対等又 はそれ以上の地位を占めたいと思うなら, インド 人以上の教育を身につけるべきであり，それはキ リスト教ミッションの教育以外にはないと説得し て, 今日のケニヤの代表的学校として知られてい る「アライアンス・ハイスクール(Alliance High School)」の設立を指導したのである(Ogoto, 1968, p.270). キリス卜教的教養を身につ
けた者が，国家の指導者なり，エリート層を形成 していくことはキリスト教布教に好都合なことで ある.教育を通じたアフリカ人社会への影響力の 確保はキリスト教ミッションにとって重大な関心 事であり,ことに学校教育の問題については植民 地政府と対立することさえあった。「アライアン ス・ハイスクール」を中心とするキリスト教ミッ ションの教育支配は，アフリカ人の政治意識を穏 健なものに変えてしまったという見方が，それで ある。「アライアンス・八イスクール」は，今日 でもケニヤのエリート層を養成する教育機関とし て存在している。「チーフ」をはじめとする植民 地政府の下級行政官であった者の一族や早くから キリスト教ミッション教育を受けた者の一族が, 植民地時代から現在まで一貫してケニヤのエリー 卜層を形成している。

1929 年のキリスト教ミッションとの対立は, アフリカ人がキリスト教ミッションの影響を拒否 する契機となった。キリスト教ミッションスクー ルから独立した学校を設立してアフリカ人自身の 手で教育を行うことを目的とする「独立学校協会 (Kikuyu Independent School)」と伝統的宗 教教育を行うための「キクユ純粋宗教学校 (Kikuyu Karinga School )」を設立して民族的教育と伝 統宗教の擁護に乗り出したのである.

\section{4. キリスト教ミッションの「女子割礼」反対 の動き}

東アフリカにキリスト教ミッションが到来した のは 1840 年代である (Osago, 1971, p.103). その後 1890 年代までの主要な活動地域は, ザン ジバル島とタンザニアであり，1877 年にはじめ てウガンダに進出した。 1891 年以前にケニヤで 活動していたキリスト教ミッションは, $\mathrm{C} ・ \mathrm{M} ・ \mathrm{~S}$ ( The Church Missionary Society), メソデ ィスト(The Methdists)のみで主としてモンバ サ周辺で活動していた. 1891年に $\mathrm{H} ・ \mathrm{G} ・ \mathrm{~F}$ (The Holy Ghost Fathers) がモンバサに進出, 更に タイタヒル (1892年), ナイロビ ( 1899 年)に進 出した. S・I・M( The Scottish Industrial 
Mission ) がキブエジに伝導所を作り（1892年）, A・I・M ( The African Inland Mission)がウ カンバニ (Ukambani )に進出して内陸部に浸透 していった.

キクュ族居住地に最初に進出して来たのは，C $\cdot \mathrm{S} \cdot \mathrm{M}$ ( The Church of Scotland Mission) である.1900年までにキクュ居住地域には $3 つ$ のキリスト教ミッションが活動していた。 C・S・ M ( The Church of Scotland Mission), G・ $\mathrm{C} \cdot \mathrm{M}$ ( The Gospel Church Mission ), A・I ・Mである. 1924 年には 14 団体がケニヤで布教 活動を行っているが，そのうちキクユ族居住地域 には 5 団体が進出していた。 C・S・M, $\mathrm{C} ・ \mathrm{M}$ • S, $\mathrm{G} \cdot \mathrm{C} \cdot \mathrm{M}, \mathrm{R} \cdot \mathrm{C} \cdot \mathrm{M}, \mathrm{A} \cdot \mathrm{I} \cdot \mathrm{M}$ であ る。（但L, R・C・Mは Holy Ghost Fathers とConsolata の 2 派を含む) ( Muriuki, 1974， pp.78-179)

キリスト教ミッションの多くは, 布教活動は各 部族語を使用することを原則としていた。宣教師 は各部族語の習得が不可欠となり，そのためアフ リカン言語の研究に熱心に取り組み，今日の東ア フリカ言語研究の基礎はキリスト教ミッションに よって築かれたといわれるくらい多大の実績をあ げた. 更に, キリスト教ミッションが各地に設立 したミッションスクールは，学校教育施設のない 時代にあって唯一の教育施設として機能した。 1910 年までに設立されたミッションスクールは 35 であったが，1924年には 69 に増加した (Osogo, 1971, p.119). そのうちキクュの居住地域の ミッションスクールは 11 校である（ナイロビは 除く. 他にメルー族, エンブ族居住地域に各 1 校). 首都のナイロビには各ミッションが 5 校開設して いる.イギリスがアフリカ人教育のため最初に設 立した学校は，マチャコス・ネイティブスクール ( The Machakos Native School) でカンバ族 の町マチャコスにおかれた。 その後, マサイ族地 区とカレンジン族地区に設立された。これらは初 等教育のための学校であって, 中等教育のための 学校は, 1924 年にナイロビに 2 校開設された。 キクュのプロテスタント系団体である $\mathrm{M} ・ \mathrm{P} ・ \mathrm{~A}$ (Members of the Protestant Alliance) が,
1926 年に「アライアンス・ハイスクール」をス タートさせた。すでに述べたように，「アライア ンス・ハイスクール」設立に関しては, $\mathrm{C} \cdot \mathrm{S} \cdot \mathrm{M}$ が大きく関与しており，その政治力を利用して， 植民地政府がアフリカ人医学校を設立するために 建設されていた建物を転用させたものである。「ア ライアンス・ハイスクール」の設立にはきわめて 大きな政治的意味が含まれていた。その影響は現 代にも及ぶ.

1924 年にキクユ族居住地域に存在する学校は, すべてミッションスクールであった，植民地政府 が設立した学校は, マサイ族, カレンジン族, カ ンバ族といった親英的部族の地域に集中している. 従って，キクユ族におけるミッションスクールの 意味は特別のものがある。 それだけに，彼らのア フリカ人自身の手によるキリスト教から独立した 学校設立の願望は切実であった。1930年代の独 立学校協会の結成や教員養成学校の設立などは, すべてこうした願望の反映である。

キリスト教ミッションによるキクュ教育の支配 は完壁であったといってよい.アフリカ人の教育 方針では植民地政府と対立した立場にあっても自 己の教育方針を堅持できた。特にイギリス系のプ ロテスタントミッションである $\mathrm{C} \cdot \mathrm{S} ・ \mathrm{M}$ と $\mathrm{C} \cdot \mathrm{M}$ ・ S は, 植民地政府から補助金を受けていて, ${ }^{12)}$ 他のミッションとは違い優遇されていた。 $\mathrm{C} ・ \mathrm{~S}$ ・ $\mathrm{M}$ と $\mathrm{C} ・ \mathrm{M} ・ \mathrm{~S}$ が植民地政府と緊密な関係にあ ったということは，それらの政治的影響力が他の ミッション以上に強いということを意味する.

ところで，キクュの「女子割礼」問題について 積極的に反対廃止運動を展開したのは，キクユ族 居住地域で布教活動を行っていた 5 団体のうち， $\mathrm{C} \cdot \mathrm{S} \cdot \mathrm{M}$ と $\mathrm{A} \cdot \mathrm{I} \cdot \mathrm{M}$ と $\mathrm{G} \cdot \mathrm{M} \cdot \mathrm{S}$ の 3 団体で ある. $\mathrm{C} ・ \mathrm{M} ・ \mathrm{~S}$ は，「女子割礼」には反対であり 廃止されるべきものと考えてはいたが，強制的に 廃止させることには賛同していない. 教育の促進 によって自然に廃止に向うのが望ましいという姿 勢である。ただ表向きには他の 3 団体と共同歩調

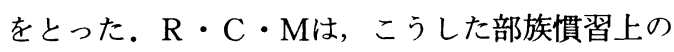
問題についてあまり関心を示していないし，カト リック系ということもあって共同歩調をとってい 
ない. 従って 1929 年に対立が表面化した後にも 積極的行動はとっていないし, 影響もあまり受け なかったようである。

「女子割礼」をめぐるキクユ族とキリスト教ミ ッションの対立は， 5 団体のうち $\mathrm{R} ・ \mathrm{C} ・ \mathrm{M}$ を除 く 4 団体との対立ということになるが，キクユ族 の側からすれば，それはそう重要な問題ではなか ったと思われる。キリスト教ミッションのもたら すキリスト教とヨーロッパ的教養がキクユ族の伝 統的部族慣習を破壊するのであるから，相手はキ リスト教ミッションそのものでなければならない し，観念的にはキリスト教とミッションスクール の教育内容でなければならなかったからだ。

キリスト教ミッション 4 団体のうち最も早く「女 子割礼手術」に反対を表明し，かつ最も強硬であ ったのは C・S・Mである.1906年にすでに反対 を表明，1916 年 7 月 16 日には，教会内で少女の 割礼を禁じる措置をとっている。1922 年には, 自分の娘に割礼手術を受けさせることを禁止，こ れに反した者は破門処分にすることを表明してい る.A・I・Mは，1914年に反対運動を開始し， 1921 年 5 月 29 日に教会内での割礼を禁止する措 置をとった。これらのキリスト教ミッションの動 きは，当初は各キリスト教ミッションの内部的問 題にとどまっていて重大な政治的社会的問題にな る程のものではなかった。しかし, 各ミッション が共同して「女子割礼手術」廃止運動を展開しは じめると，それは大きな社会問題となる。更に植 民地政府を動かして廃止のための立法措置をとろ うとするに至ると政治問題に発展せざるを得なか った。

キリスト教ミッションは，なぜこうしたキクュ 族の慣習に立入って「女子割礼手術」の廃止運動 を強力に展開したのであろうか.

その第 1 の理由は健康上, 衛生上の理由からで あった。ミッション附属の医療施設から「女子割 礼手術」は，しばしば少女の身体に重大な後遺症 を残し成人してからの出産の際に障害を生じるば かりか，著しいときには生命の危険さえ招来する という報告がなされていた，医学的にみた場合の この「割礼手術」の問題点として，キクュランド
で働いていた 4 人の医師の証言によれば，「この 手術は，産道のまわりの柔らかい部分を内外部に わたって切除することから成っている．もっとも ひどい形では，切除が恥骨や産道に達するものが あり，そのためこの周辺の弾力性のある通常の組 織が取り去られてしまう. 又, これらの部分は非 常に鋭敏な部分であるからその切除には大変な苦 痛を伴うものである。この手術の影響は，キクュ ランドの医療活動中，次のようなものとして認め られた。

(1)膀胱の污染。腎臓の污染に扡大する危険があ る. (2)性行為不能による不妊.

この為,「割礼手術」は，しばしば我々医師が 行ってきた。もっとも重大な影響は出産の場合に おこる，承知のように，胎児が産道を通過すると き産道は非常に拡張されるが，「割礼手術」によ って柔軟な筋肉組織が切除されているため,この 拡張が困難になる. 従って, 初産の場合には胎児 の死亡を招来する。 それを避ける為には切開手術 をしなければならず，このとき直腸に切り込まれ ることがあり，妊婦は自分で運動することができ なくなる．すべての場合に傷が化膿し体内污染の 危険が生じ致命傷になったり，ひどい後遺症とし て残る。我々は多くの初産妊婦をあつかったが, みな切開手術が必要であった.」(Murray-Brown, 1972，p.326 ) とのことである.

これは，キリスト教ミッションの主張する「女 子割礼」の肉体的危険性である。

第 2 の理由は，布教活動の面からである.

「割礼手術」は非常な苦痛を伴うから，これを 避けようとしてミッション施設に保護された少女 を，両親や部族長老が無理遣り連れて帰り「割礼 手術」を受けさせたり，あるいはミッションスク ールの寄宿舎に入っていた少女が割礼年齢になる と部落に連れていかれ「割礼手術」を受けさせら れる。「割礼手術」に伴う精神的苦痛があまりに も印象的で少女達の精神面に悪影響を残し，せっ かくキリスト教の精神世界に入っていた彼女達が， そのために部族の伝統的精神世界に引き戻され布 教効果が減殺されてしまうと考えられた(Tignor, 出版年不明, p. 236 )。この点は, 相当に主観的 
問題なのでミッションによってはあまり重要視し ないところもあるが， $\mathrm{C} ・ \mathrm{~S} ・ \mathrm{M}$ の第一線のミッ ション関係者の多くはそう信じていたといわれる. 割礼儀礼は，ユダヤ教徒の間で広く行われてい たし，キリスト教徒の間でも行われていた時代が あった。パウ口によってその廃止が主張されて以 来, 今日ではキリスト教徒の間で割礼が行われる ことはない。キリスト教ミッションが割礼廃止に 積極的なのは，このことと無縁ではないであろ j.13)

「女子割礼手術」の廃止を主張するキリスト教 ミッション 4 団体は, 単にミッション内にとどま らず，植民地政府にそのための立法措置をとるよ う要請した。しかし, 植民地政府の態度は必ずし も好意的なものではなかった。1926 年のアフリ 力総督会議では，「慣習は，古い歷史をもつもの であるから阻害すべきではない，もしその慣習を 止めさせるにしても，その部族を説得して自主的 に止めさせるか，あるいは “より害の少い方法” に変えさせるかのどちらかにする.」( MurrayBrown, 1972, p.136) 旨の合意をしている。 “よ り害の少い方法”とは, 割礼手術に伴う切除部分を できるだけ少くすること，施術者を地方議会により 資格を認められる熟練した女性に限ること，など である。切除部分の少い割礼手術は「小手術」と 呼ばれ，危険度を少くするために「小手術」に限 定して認めることになった。

植民地政府が動かず立法的措置が望めないこと を知った $\mathrm{C} ・ \mathrm{~S} ・ \mathrm{M}$ は, ミッション関係者の力に よってこの運動を更に強力に展開することを申し 合せるべく, キクユ族居住地で布教活動を行って いる全ミッションに出席を要請して「ッムッム会 議」（ C・S・Mの伝道所がある地名 )が開かれた. この会議で, 次のことが申し合わされている.

(1)「割礼手術」は悪 ( evil) である。すべての ミッション関係者は，これを廃止しなければなら ない.

(2)「割礼手術」を行うキリスト教徒は，すべて のキリスト教ミッションにより破門される.

この会議は, キリスト教ミッションの強い決意 を改めて表明したものと受けとられたが，「割礼
は悪である.」としたところに，その尋常一様で ない態度を感じさせる。この申し合せには, カト リック系の $\mathrm{R} ・ \mathrm{C} ・ \mathrm{M}$ を除いた 4 団体が賛同して いる ( Murray-Brown, 1972, p.136).

しかし,こうしたキリスト教ミッションの「女 子割礼手術」に対する攻撃は, キクュの大方の強 い反発を呼んだ。キクュの政治団体である $\mathrm{K} ・ \mathrm{C}$ -A ( Kikuyu Central Association) は, 「部族 慣習を守れ」と主張して反キリスト教ミッション の立場を鮮明にした。

1929 年 8 月に, キクュとキリスト教ミッショ ンが正面から対決する事件が执こった。キフムブ イ二事件と呼ばれるものがそれである.キフムブ イニ (地名) にある $\mathrm{G} ・ \mathrm{C} ・ \mathrm{M}$ の寄宿舎から 14 才になるキクユ少女が，割礼手術を受けるため 強制的に連れ去ら, 周囲の圧力のもとで手術 に同意させられ「割礼」を受けた。 $\mathrm{G} ・ \mathrm{C} ・$ Mは,これを傷害の罪としてケニヤ警察に告 発した。裁判の結果, 裁判所は傷害の罪とし てではなく「小手術」のかわりに「大手術」 を行っていたという点のみを問題にして罰金刑を 関係者に言い渡した。判決は，ケニヤ・ハイコー 卜 (控訴院) でも支持された. $\mathrm{G} \cdot \mathrm{C} \cdot \mathrm{M}$ は, こ の判決に非常な危機感をもった。キリスト教ミッ ションの運動が, 裁判所によって, ひいては植民 地政府によって否定されたことにも等しいからで ある，G・C・Mの責任者アーサー・バロウ（Athur ・ Barlow ) は, イースト・アフリカ・スタンダ 一ト紙 ( The East Africa Standard)に投書し てこの裁判を批判した ( The East Africa Standard 紙，1929，8月10日）。そして，植民地政 府に対しては，「個人の良心を守る」べきことを 強く要請し, $\mathrm{R} \cdot \mathrm{C} \cdot \mathrm{A}$ を除く他の 3 団体の代表 者をカべテに招集して「女子割礼廃止運動」の継 続を内容とする声明を発表した。このとき, 彼は キクユ内で $\mathrm{K} ・ \mathrm{C} \cdot \mathrm{A}$ と対立関係にある $\mathrm{K} ・ \mathrm{~A}$ (Kikuyu Association) の代表者の出席を求め 協力を要請しているが全面的賛成は得られなかっ た。

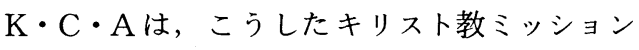
の動きにすぐ反応した．委員長ジョセフ・カンゲ 
ゼ ( Ioseph Kangethe)は,アーサー・バロウ (Athur Barlow) に対し，ヨーロッパ人がキク ユの慣習を妨害する理由はどこにもない，と反論 した. $\mathrm{K} ・ \mathrm{C} ・ \mathrm{~A}$ 活動家は，ミッションの日曜集 会に出席しては，これらの声明を批判し撤回を求 めた， $\mathrm{G} ・ \mathrm{C} ・ \mathrm{M}$ の教会のみではなく, $\mathrm{A} ・ \mathrm{I} ・ \mathrm{M}$ や C・S・Mの教会でも同じような事態が発生し て，キリス卜教 3 団体と $\mathrm{K} \cdot \mathrm{C} \cdot \mathrm{A}$ の全面対決の 様相をおびて来た， G・C・M， A・I・M，C・ $S \cdot M の 3$ 団体は，「女子割礼」廃止運動に賛同 しない信者の施設への立入りを拒否すると同時に， $\mathrm{K} \cdot \mathrm{C} \cdot \mathrm{A}$ のメンバーとなっているミッション関 係者を追放してこれに対抗，あくまでも「女子割 礼」廃止運動を続ける. 当時, $\mathrm{K} \cdot \mathrm{C} \cdot \mathrm{A}$ 書記長 として反キリスト教ミッション運動を指導したジ ョモ・ケニヤッタは，「女子割礼問題」について 次のようにいっている.

「この問題の論点は, 単なる外科手術的側面に あるのではなく，キクユ族の部族社会の心理的側 面にある重要な事実を理解するかどうかなのであ る。つまり，割礼儀礼は，その外科手術そのもの とは別に，重大な教育的・社会的・宗教的意味を むつきわめて本質的制度として考えられている。 現在では，キクュの人々が，この割礼手術のない 割礼儀礼を想像することは不可能である。それ故， キクュの人々にとって，この慣習に伴う外科手術 をやめることは部族慣習全体の廃止を意味する。

「イルア（割礼集団）」の廃止は，エイジグルー プ (Age-Group)の識別という部族的シンボル を破壊し，伝統的に維持されて来た部族の団結力 と部族愛精神を永久にキクユから取り去ってしま 5.」( Kenyatta, 1968, pp.133-135)

キクユ族の人々にとって，男子割礼であれ，女 子割礼であれ, 割礼儀礼を廃止すること自体が, 即部族社会の崩壊に至るというのであるからキ リスト教ミッションの「女子割礼」廃止運動はキ クユに対する敵対行為以外の何物でもなく，その 主張は決して容認されるべきものではなかった。

「割礼制度」がいかにキクュの部族社会制度の 根底にあり，それを中心に社会制度が動いて来た かは，キクユ族の人々なら誰でも理解できたから，
$\mathrm{K} \cdot \mathrm{C} \cdot \mathrm{A}$ の運動は広く人々に浸透して，1930年 末には，すべての地区に $\mathrm{K} ・ \mathrm{C} ・ \mathrm{~A}$ の支部ができ た.

1930 年に入ってもキリスト教ミッションとキ クュ族, $\mathrm{K} ・ \mathrm{C} \cdot \mathrm{A}$ との対立は続いた。 ジョモ・ ケニヤッタ $\mathrm{K} \cdot \mathrm{C} \cdot \mathrm{A}$ 書記長は, $\mathrm{C} \cdot \mathrm{S} \cdot \mathrm{M}$ の代 表と会い，キリスト教ミッション 4 団体の反対に もかかわらず，「女子割礼」は継続する方針であ ることを告げ, この問題で妥協する余地がないと 表明している。

$\mathrm{C} \cdot \mathrm{S} \cdot \mathrm{M}$ も強硬であった， $\mathrm{C} \cdot \mathrm{S} \cdot \mathrm{M}$ の施設 で働く自己の代理人に， $\mathrm{K} ・ \mathrm{C} ・ \mathrm{~A}$ に反対する宣 誓を求め, ミッションスクールの教師は $\mathrm{K} ・ \mathrm{C} ・$ $\mathrm{A} の$ メン゙ーであってはならない.メンバーであ る者は脱会しなければ雇用しないとした，あるミ ッション施設では 53 人のうち 12 人が，この要求 を拒否して施設を去ったといわれる（MurrayBrown, 1972, p.137).

1930 年 1 月に, $\mathrm{A} ・ \mathrm{I} ・ \mathrm{M}$ の関係者が 1 人殺害 されて，事態は一層深刻化していた。この事態を 機に植民地政府が $\mathrm{K} \cdot \mathrm{C} \cdot \mathrm{A}$ の取締りに乗り出し， キリスト教ミッション 4 団体と $\mathrm{K} \cdot \mathrm{C} \cdot \mathrm{A}$ の対立 は, 再び $\mathrm{K} \cdot \mathrm{C} \cdot \mathrm{A}$ と植民地政府との対立に進展 した。キクュの人々にとっては，キリスト教ミッ ションの背後にいる植民地政府, 即ちイギリスこ そ本当の相手であることが明らかになったことで, $\mathrm{K} \cdot \mathrm{C} \cdot \mathrm{A}$ の運動が反英運動に向う転機となった。

1930 年代の K・C・A 運動は, 労働運動や教 育活動を中心に展開され，そのもっともラディカ ルなエネルギーが， 1950 年代の「マウマウの反 乱」へと結実していった。

ところで，「割礼廃止」が部族崩壊に至るとい うキクュの主張を理解するためには,「割礼制度」 がキクユ族社会においてどのような役割を果して いるかをみておかなければならない。

\section{5. キクユ族の社会制度と割礼}

割礼とは生殖器の一部を切除することによって 成人社会への移行を社会的に公認しようとする社 会慣習 (通過儀礼) の一種である. 通常, 誕生後 
間もなくか，又は思春期に行われる．宗教的儀礼 の意味あいが強い。

割礼の起源については明確にされていないが， 相当古くから世界各地で行われていたと考えられ ている. 紀元前 2400 年頃とみられるエジプトの サッカラ（Sakkara）の墓の壁に「割礼手術を受 けている少年」の図が描かれていることから，エ ジプトでは紀元前 4 千年頃にはすでに割礼は行わ れていたとする説もある。

割礼の社会的意義は，一般的にいえば，ある一 定の社会の中での成人社会への移行を公認するた めの通過儀礼である，それを終了することで，は じめて 1 人前の社会構成員として認められる.割 礼を受けた者のみが，その社会における社会的地 位，権利，義務の取得と享受を認められ，社会集 団人の帰属を公認されるものである，勿論，割礼 のもつ社会的意義が，そのような一義的なものに 限定されているのではなく，各部族社会それぞれ に多様な意義をもつものであることはいうまでも ない.

キクユ族における割礼の社会的意義も，やは りそれと同じょうに考えられている。割礼は， キクユ社会の中での子供世界から大人世界への 脱却と入会である。割礼によりキクユ社会の正 式な部族構成員として認められ，社会的地位 とそれぞれの社会集団での権利・義務が与えら れる。キクユ族の場合, 割礼により男は「戦士」 として社会防衛の義務を負い，女は「結婚する」 ことが認められる. 割礼年齢は, 男は 16 才〜 17 才，女は 10 才〜 14 才とされ，割礼が行われる時 期は収穫期が終る 1 月から 4 月頃までの間で，地 域的に多少のずれがある．割礼年齢に近づいた少 年，少女は狩りや遊びのために一定のグループに 集められ，それぞれ固有の名称をつけられる。こ れが「エイジ・セッツ (Age - Sets )」と呼ばれる もので，割礼を同一時期にうける世代としてその 後の社会生活単位となり重要な役割を果す。割礼 を終えた少年は「戦士（Anake）」として戦闘技 術, 出陣ダンス, 伝統的作戦などの必要な事項を 年長の「戦士」から教えられる. 更に部族生活 に必要な知識, 例えば部族伝承, 宗教儀礼,
タブー, 行動作法なども割礼儀礼の一部とし ておしえこまれる。そこでは割礼が一種の教育手 段として利用されている．女子の場合も，男子と 同様に，割礼を受けなければ 1 人前のキクユ女性 とはみなされない。割礼を受けてはじめて結婚す ることを認められ，キクュ女性としての心構え， 家事，ダンスなどの必要事項を年長者から習うこ とができる。

「戦士」階級を構成する「戦士」は，割礼を終 了した 17 才〜 40 才の男の役割で，「エイジ・セ ッッ」の集団が形成する。「戦士」は年長になり 結婚すると「戦士」を指導する地位につく資格を 認められる．更に「戦士」を退役した者は，「長 老会議（キアマ：Kiama）」に入る資格を与えら れる。「キアマ」は，部族の政治的運営機関であ って，「キアマ」に属する長老グループの中から 現実に部族運営に当る者が選ばれる.主てして「エ イジ・グレイド ( Age-Grade )」を基準に選ばれ, (1)ムワンギ ( Mwangi ) と(2)マイナ( Maina) と

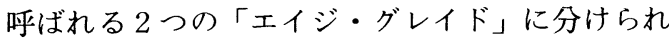
ている. 現実の政治は，この 2 つの「イジ・グ レイド」が交代で当り，1 世代の担当機関は 30 年〜 40 年ということである。

「キアマ」の中に部族内司法を担当する長 老や宗教事項を担当する長老グループがあり， 彼らは部族社会の中の最高の地位にあるとみ なされている，その入会資格は，自分の子供が割 礼を終えた時，あるいは，全部の子供が割礼を終 えた時に取得する。

キクユ族の部族社会の単位や部族運営組織に入 る資格の取得が，すべて割礼儀礼の終了を契機と していることからもわかるように，割礼儀礼が， 部族社会制度の根底におかれている。

「割礼儀礼は，子供の価值感，特に青年世界か らの離脱という完成を象徵するシンボルとして強 調される。そこで，割礼儀礼が若者に社会的地位 を与え，社会の構成員であることを認める．成人 社会への新参者が部族に伝わる知識を教えこまれ るのもこの時点からである。この教育（Kuumithio ) は, 割礼儀礼の肉体的側面と同様に重要な ものと考えられている. 実際，割礼に伴う教育を 
受けていない者は，いかなる意味でも割礼を受け たものとはみなされない，その結果，一生仲間は ずれにされる. 恒常的教育施設が設けられていな いため割礼儀礼がキクユ社会における主要な教育 手段とされている. 教育は, 実践・理論両面から 部族伝承・宗教・行動規範・義務・タブー・セッ クス等々, あらゆる面に及ぶ。割礼儀礼は, 社会 制度内での責任と権利を附与し, 彼ら自身の間で は同志愛・兄弟愛の強い絆をもつグループとして, エイジ・セッツの相互扶助と団結が要求される.リ イカ（riika =Age-Sets）は，兄弟のように互 に尊敬し合い行動する.」( Muriuki, 1974, pp. $118-119)^{14)}$

以上のように, キクユ社会における割礼儀礼の 意味は, 教育手段であり社会運営手段であって, そこから部族全体の団結力と部族愛精神を育むの である。キリスト教ミッションのいうように割礼 を廃止すれば, 部族の精神的支柱, 社会制度の支 柱を失うことになって部族社会の崩壊に至ると考 えられた。

ただ注意しておくべきことは，キリスト教ミッ ションが主張しているのは「危険な割礼手術」そ のものをやめよといっているのであって制度とし ての割礼儀礼をすべて廃止せよといっているので はなかった。「女子の割礼」の際に行われる「割 礼手術」があまりに女性の身体を傷つけ女性とし ての機能に障害を及ぼすが故に「割礼手術」をや めよと主張している。「割礼儀礼」がどのような 社会的意義を有するものであるか，あるいは何故 にそのような「割礼手術」を行うかという点は まったく問題にしていない。ただ「割礼は悪で ある.」という意識に基づいてキリスト教ミッ ション 4 団体は一致団結して廃止運動を展開した のである。運動がキリスト教に帰依したキクユの 信者に対する啓発運動としてキリスト教ミッショ ン内部にとどまっている限りでは大きな問題に発 展寸る余地はなかったであろう。キリスト教ミッ ションが，立法措置をとってまでキクュの部族慣 習を廃止させようとしたことが，キクュのすべて の階層の人々の反発を招き，深刻な対立に至った 原因である。

\section{6. キリスト教ミッションとキクユ族の対立の 影響}

ケニヤには，最大部族のキクユ族をはじめ 40 を超える部族がいる。「割礼」という部族慣習上 の問題でキリスト教ミッションと対立したのはキ クユ族以外にはない，東アフリカ全域をみても

「割礼」でこれ程までに対立した部族があったで

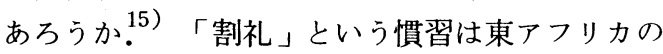
大多数の部族がもっているのである。ただキクュ 族のような「女子割礼」の慣習をもつ部族は大変 少い。「女子の割礼」が，それ自体特殊な慣習と いう訳ではなく，世界的にみても広い範囲に分布 している。一説によれば男子の割礼より古い時代 にさかのぼるといわれている。

キクユ族に隣接する部族であるマサイ族も「女 子割礼」の慣習をもっているが，彼らはキリスト 教ミッションと対立することはなかった。ケニヤ 内陸部で最初にミッションスクールに入ったのは 22 名のマサイ族の少年であったという事実が示 す通り，彼らがミッションと無関係の状態であっ た訳ではない( Ogoto, 1968, p.261).ただ， 、 サイ族の置かれた政治状況を考慮すれば，ある程 度はその理由を推測できる。

1890 年前後のマサイ族は, 部族内戦と飢饉の ために部族が崩壊した状態で, 多数のマサイが難 民化し，隣接部族に救いを求めていた。イギリス は，彼らの勇猛さと戦闘能力を高く評価してアス カリ（兵士）として採用, 他部族の討伐作戦に投 入した。そこからマサイはもっとも親英的部族と みられてきた，次にマサイ族は本来が遊牧民で定 住性に欠け，キリス卜教の布教効果が相対的に低 いうえ，独自慣習に固執する傾向が強いとみられ ている. マサイ族の「女子割礼手術」は切除部分 が少く, その危険性が低いとみなされていた。 そ の「割礼手術」は東アフリカ総督会議が「より害 の少い方法」と認定した, いわば「小手術」に相 当するものだった.

一方，キクユ族においては，「ホワイトハイラ ンド化」にみられるように土地問題で, 植民地政 府と深刻な対立関係にあり，イギリスは危険部族 
として警戒している。キクユ族の政治意識は 1920 年代に高揚し， $\mathrm{K} ・ \mathrm{C} ・ \mathrm{~A}$ のような新しい政治団 体が存在していた。こうしてみると，キリスト教 ミッションとキクユ族の対立はキクユ族のおかれ た厳しい政治状況を抜きにしては考えられない。 そして，この対立を通じて， $\mathrm{K} ・ \mathrm{C} ・ \mathrm{~A}$ がキクュ 大衆の支持を得ることができたし，よりラディカ ルな部分が生まれた。キクユ族が，みずからの手 で子弟教育を行うためにキリスト教ミッションか ら独立した学校を設立し運営していく独立学校協 会を組織することになり，更にキクユの宗教活動 と宗教教育のためのキクユカリンガ・スクール ( 純粋宗教学校) の設立をはじめるきっかけにな った.

この点については, キリスト教ミッションとの 対立がきっかけとなったといえる証拠はないとす る説がある( Murray-Brown, 1972, p.147). 独立学校設立の導きは 1920 年当初から散見され ているし，設立許可が必ずしもスムースにいかな かっただけにすぎないという。しかし，いずれに せよここの対立以降にそうした宗教・教育に関す るキクユ独自の動きが活発になったことは事実で ある。

キクユの文化的独自性とキリスト教文化の正面 衝突法他でもない「ヨーロッパ的近代化」への民 族主義的反発といってよいであろう。こうした民 族主義の流れは，「近代化」を主張するキクユの 政治的リーダーに対しても一定の距離をおき，反 英反植民地主義という形をとって，20年後の「マ ウマウの反乱」に向って流れていく， $\mathrm{K} ・ \mathrm{C} \cdot \mathrm{A}$ の指導的メンバーは, キリスト教ミッションの 「女子割礼」廃止運動に反対したけれども，「女 子割礼」の慣習を積極的に維持するための努力を した訳ではない, 彼らは, 単に運動課題としてそ れに取り組んだだけのことで，個人的には，慣習 を廃止するか存続させるかは, キクュの人々が自 主的に決定することであるからという反対理由を もっていたのだった。この考え方は，C・M・S の態度に近いのである。

$\mathrm{K} \cdot \mathrm{C} \cdot \mathrm{A}$ が, 政治団体として大衆的支持を得 ることはできたとしても，指導的メンバーは依然
キクュの大衆的意識構造とはかけ離れた存在であ ったことに変りはなかった。 反キリスト教ミッシ ョン感情は, キリスト教ミッション教育を受け入 れて経済的富を追求する新興勢力に対する反発も 強めた。

1920 年代のキクュの政治運動は, ケニヤ独立 運動の 1 つの原点であり，なかでもキリスト教ミ ッションとの対立はキクュナショナリズム運動の 原点であった。そうした意味で，1950年代のキ クユの反英独立運動にも大きな影響を及ぼし, 今 日のケニヤの政治状況にも媣い関倸をもっている.

\section{7. おわりに}

ケニヤの各部族の社会構造は, 中央集権的社会 構造ではなく，王を中心とする王制でもなかった。 多数の部族長老を中心とする集団的部族運営が行 われていた。イギリスは，植民地統治を開始する にあたり,こうした社会構造を見落したために 「チーフ制度」が導入され，植民地統治のなかで 最初の新興勢力が出現した. 次に, キリスト教ミ ッションの設立したミッションスクールで教育を 受けた者が第 2 の新興勢力を形成する。「チーフ」 をはじめとする植民地政府の末端行政官に任命さ れる者も，ミッションスクールの教育を受けた者 も，ともに伝統的社会では下層に属する若者達で あった。キクュにおいては, アホイ(Ahoi) と 呼ばれる土地非所有者がそれに当る。キクュの アホイは，イギリスの土地政策の影響をまとも に受ける層で，耕作すべき土地をもつチャンス がなかった，彼らの多くは若者で，「チーフ」 に任命されることを強く願望し，あるいは社会進 出の手掛りとしてミッションスクールに集まった。 キクユ居住地域では, ミッションスクールしか教 育を受けるチャンスはなかったからだ。

この結果，イギリス植民地統治時代には 4 つの グループが社会階層として形成された。(1)伝統的 社会の長老など旧社会の上層グループ. (2)植民地 政府に協力する末端行政官, 警察官, 兵士 (但し, キクユ族から兵士に採用される者は極端に少い. ) (3)キリスト教ミッションスクールの教育を受けた 
グループ，(4)以上 3 つの゙れにも属さず伝統的社 会の下層グループ.

このうち，伝統的社会の下層グループ，キク ユ社会ではアホイと呼ばれる人々が，(2)，(3)，

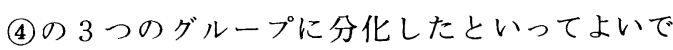
あろう。(3のグループは主として経済的利益の 追求に力を入れたが，(4)のグループは，ヨーロッ パ農場の労働者や政府・企業の労働者に流れて いった。

キクユの独立運動の中では中立的又は穏健な立 場を占めていたのは(3)のグループで, 必ずしも植 民地統治を否定してはいなかった（4)のグループ は，よりラディカルな運動の主体となって，K・ $\mathrm{A} \cdot \mathrm{U}$ や $\mathrm{K} \cdot \mathrm{C} \cdot \mathrm{A}$ の下部活動家層を形成し, 「マ ウマウの反乱」に参加する. 独立後のケニヤで政 権を担当し社会の上層を占めるのは，(2)と(3)のグ ループである。1920年代の $\mathrm{K} ・ \mathrm{C} ・ \mathrm{~A}, 1940$ 年 代の $\mathrm{K} ・ \mathrm{~A} ・ \mathrm{U}$ の指導的メンバーは(3)のグループ からなっている.

今日, もっとも冷遇されているのが(4)のグルー プである。「土地問題」の最大の被害者として, その解決と民族独立を主張して立ちあがったのが 「マウマウの反乱」であったが，鎮圧されたが故 に，独立後も彼らの土地問題は依然解決されず今 日に至っている．しかし「マウマウの反乱」とい うイギリスにとって衝撃的な反乱が，ケニヤ独立 に決定的ともいえる役割を果したことは明らかで ある. 多数の部族をかかえ部族対立の危険を常に 内包する国内政治において単一部族の反乱を国家 独立の原動力と賛美するのには多くの抵抗がある。 同じキクュ族でも「マウマウの反乱」を否定する 層が政治権力の中枢を占めて来た現状で，彼らが 正当な評価を受けるまでには多くの時間を必要と するであろう。

今日，キリスト教ミッションが植民地主義時代 に果した役割について多くのことが語られている. その当否は別にしても，彼らが，社会的政治的問 題の形成に深いかかわりをもっていたのは事実で あり，その影響力は現在でもなお存在している。 そして, 必要ならば自らの利益を守るために積 極的に行動してきた。ケニヤにおける，キリスト
教ミッションの「女子割礼」をめぐる動きはその ひとつの例である.

東アフリカ地域に「インド人問題」と呼ばれる 政治的社会的問題があることはよく知られている. それは,・植民地時代に入植したヨーロッパ人とイ ンド人の政治的経済的利害対立に端を発している のであるが，植民地が独立した後は，「インド人 の流通支配」の問題としてクローズアップされて いる．現在，東アフリカではインド人は必ずしも 好ましい感情をもたれる立場にはない。アフリカ 人の多くは，むしろヨーロッパ人に好意を示す. 勿論ヨーロッパ文明への憧れがあることはいうま でもないが，彼らが植民地支配者であったことを 考えれば，インド人やアラブ人に対するとは違っ た感情があってしかるべきであろう，古くから奴 隷制を持ち込んだアラブ人に対してもさほどの反 感は感じられない。あまり影響を及ぼしていると は思えないインド人が一番微妙な立場にあるのは 奇妙でさえある。こうしたインド人の立場は，キ リスト教ミッションのアフリカ人教育の影響では ないかという疑問が生じる。確証はないが，その ひとつの例が，アフリカ人とアジア人 (インド・ パキスタン系）の同盟を阻害した 1920 年代のキ リスト教ミッションの動きではなかったかと推測 できるのである.

1952 年から 1960年のケニヤの政治的動きを理 解しなければ，独立後のケ二ヤを理解できないと いうのは，十イロビ大学のオゴト教授 (B・Ogoto) である. 1952 年から 1960 年の動きを理解するに は，1920年代の政治状況を理解しなければなら ず，とりわけキリスト教ミッションの動きは注目 すべきである.

「マウマウの反乱」の最大の要因は，「土地問 題」と「キリスト教, ヨーロッパ文明」と「労働 問題」の 3 つに集約できるのではないであろうか. その他の問題はすべて, これらの問題に起因する 派生的なものである。その評価は，いろいろある けれども「民族独立運動」であり「階級闘争」で あったと考えられる。

今まで， $\mathrm{K} ・ \mathrm{~A} ・ \mathrm{U}$ と「ウマウ団」の区別は 必ずしも明確でなかった。イギリス側が，「マウ 
マウ団」は $\mathrm{K} ・ \mathrm{~A} ・ \mathrm{U}$ の秘密軍事組織とみていた ことはすでに述べたが， $\mathrm{K} ・ \mathrm{~A} ・ \mathrm{U} の$ 穏健派と武 闘派の分裂の結果とみる見方も強かった。しかし 「マウマウ団」の生存者が,「マウマウ団」と $\mathrm{K}$ ・A・Uとは当初からまったく別の組織であった ことを明らかにしている，E・A・A ( East Africa Association ) や $\mathrm{K} \cdot \mathrm{C} \cdot \mathrm{A}$ を構成する指 導的メンバーの考え方は, 1946 年の $\mathrm{K} ・ \mathrm{~A} ・ \mathrm{U}$ の運動に吸収され，更に今日のケニヤの政治指導 層に維持されている。「マウマウ団」の主張する 「土地問題の解決」と「自由・独立」という点は, そうした表面上の流れとは別なところで流れてい た。それに最も影響を与えたのが，1929年のキ リスト教ミッションとの対立にはじまる政治状況 であった。

以上

\section{注}

1) $\mathrm{Mau} \mathrm{Mau}$ とは，ヨーロッパ人がつけた通称であ る. 正式名は, Kenya Land and Freedom Army という.

2) Anake a 40 ( 40 年組) と呼ばれて，1946年12月 15 日の $\mathrm{K} \cdot \mathrm{A} \cdot \mathrm{U}$ 集会で, J. Kenyatta の演説の中の $\ulcorner$ Anake a 30 ( 30 年組)」という言葉にヒントを得 て1947年1月に結成される. その後解散するが，主 要メンバーはマウマウに参加した.

3）イギリス側の討伐作戦については以下参照. Majdalary, F.1962. State of Emergency, Longmans, London.

Clayton, A. 1976. Counter-insurgency in Kenya. 1956-1960, Trans-africa Pubjishers, Nairobi.

4) Bildad, Kaggia. Fred Kubai らが元ナイロビ 中央委員, 元 $\mathrm{K} \cdot \mathrm{A} \cdot \mathrm{U}$ 中央委員. Itote, $\mathrm{W}$. ケニヤ山 地区のゲリラ戦リーダー. Kariuki, J・M. キクユ族 出身の国会議員.

5）Mau Mau のメンバーではないが，1952 年から 1960 年まで拘留される. 独立後, 国会議員となるが, ケニヤッタ政権を批判したとして 1975 年 3 月暗殺さ れる. 元・ $\mathrm{K} \cdot \mathrm{A} \cdot \mathrm{U}$ メンバー

6) Nairobi City Councilの労働組合指導者, ルオ 族の代表的政治家の 1 人. 独立後, 国会議員, 経済相, 1969 年暗殺される.

7) The Young Kikuyu Association, 1921 年 6 月 7 日結成され， 7 月 10 日に, The East Africa Association と改称, 更に The Kikuyu Central Association と名称をかえた.

8）ハリー・ック事件. 公式発表では死者 27 名，負傷
24 名 (一説では 150 名死亡ともいう)，1922 年 3 月 16 日, メトロポールホテル前 (現在 ナイロビ大学 構内 ) で発生した.

9）1906年に設立された $\mathrm{C} ・ \mathrm{M} \cdot \mathrm{S}$ の Maseoミッショ ンスクールの卒業生を中心に組織され, 初期 $\mathrm{K} ・ \mathrm{C}$ ・ A と同様,「自己改善運動 (Self-improvement)」 を目標に活動した.

10) Hut and Pull Tax 1920 年に 5 シリングから 10 シリングに引きあげられ，1921 年に 8 シリングに 下がったが，賃金は 3 分の 1 に引き下げられた.

1915 年成立の Regisration Ordinance が 1920 年に発効され，Kipande が導入された.「指紋入り 身分証明書」の携帯が義務づけられた.

11）アライアンス・ハイスクールからナイロビ大学のコ 一スが最高のエリートコースとされている.

12）生徒 1 名あたり 2 ポンドの施設補助費と政府機関の 試験合格者 1 名あたり 5 ポンドの奨励金が支出されて いた. 1916 年以降は, $\mathrm{C} \cdot \mathrm{S} \cdot \mathrm{M}$ と C・M・S に限ら れている. 1927 年になってカトリック系ミッション スクールが対象となる.

13）特にイギリス系プロテスタントミッションが積極的 である.

14）他にKikuyu の割礼制度につき下記参照.

Beecher, L. J. 1944. The Kikuyu, 出版社不明, Nairobi.

Kenyatta, J. 1938. Facing Mt. Kenya, Secker \& Warburg, London.

Lambert, H. E. 1956. Kikuyu Social and Political Institution, Oxford University Press, London.

Maina, K. 1969. Kikuyu Studies, African Studies Association, Montreal.

15）資料上の限界のため確証は得られない. 


\section{参考文献}

Anderson, J. E. 1970. The Struggle for the School. Longman. London.

Barnet, D. L. and Njama, K. 1966. Mau Mau from within. New York Monthly Review Press. New York.

Barnet, M. 1956. The Kings African Rifle. Gale \& Polden. London.

Colonial Report 1953. Colonial Report Kenya. Colonial Office. London.

Carothers, J. C. 1954. The pshchology of Mau Mau. Government Print. Nairobi.

Itote, W. 1967. Mau Mau General: General China. East Africa Publishing House. Nairobi.

Kagia, B. 1971. Root of Freedom. East Africa Publishing House. Nairobi.

Kariuki, J. M. 1963. Маи Mau Detainee. Oxford Univerity Press. London.

Kipkorir, B. K. 1969. The Alliance High School and the Origins of the Kenya African Elite 1926-1962. Ph.D. thesis. Cambridge. London.

1972. The Education Elite and Local Society: in Politics and Nationalism in Colonial Kenya. East Africa Publishing House. Nairobi.

Kenyatta, J. 1968. Suffering without Bitterness. East Africa Publishing House. Nairobi. 1938. Facing Mt. Kenya: The Tribal Life of the Gikuyu. Secker \& Warburg, London.

Leakey, L. S. B. 1952. Mau Mau and The Kikuyu. Methuen. London.

1954. Defeating Mau Mau. Mathuen. London.

Lambert, H. E. 1956. Kikuyu Social and Political Institution. Oxford University Press. London.

Muriuki, G. 1974. A History of The Kikuyu 1500-1900. Oxford University Press. Nairobi.

Mangat, J. S. 1969. A History of the Asian in East Africa 1886-1945. Oxford at the clarendon Press. London.

Majadalany, F. 1962. State of Emergency: the full story of Маи Mau. Longmans. London.

Mboya, T. 1956. The Kenya Question: an African answer Fabian Colonial Bureau. London.

Murray-Brown, J. 1972. Kenyatta. G. Allen. London.

Nottingham, J. \& Rosberg, C. G. 1966. The Myth of Mau Mau. East Africa Publishing House. Nairobi.

Ogoto, B. A. 1968. Kenya Under the British 1895-1963: Zamani. East Africa Publishing House. Nairobi.

1972. Revolt of the Elders: an anatomy of the loyalist crowd in the Mau Mau uprising 1952-1956. East Africa Publishing House. Nairobi.

1967. Hadith I. East Africa Publishing House. 1970. Hadith II. East Africa Publishing House. 1971. Hadith III. East Africa Publishing House.

Nairobi.

Osogo, J. N. B. 1971. Educational Development in Kenya 1911-1924: Hadith III.
Ochieng, W. \& Ogoto, B. A. 1972. A War and Society in Africa: Munboism Anti-Colonial Movement. Frank Cass \& Co., Ltd., Portland Oregon.

Odinga, O. 1967. Not Yet Uhuru. Heinemann. London.

Parlimentary Paper.1925. Report of the East Africa Commission. Cmd 2387.

1929. Report of the (Hilton Young) Commission on Closer Union of the Dependencees in Eastern and Central Africa. Cmd 3234.

Robert, B. 1973. Mau Mau Twenty Years after. The Hague. Monton.

Smith, S. J. 1973. The History of Alliance High School Heinemann. Nairobi.

Singh, M. 1969. History of Kenya's Trade Union Movement to 1952. East Africa Publishing House. Nairobi.

Sorrenson, M. P. K. 1968. Land Reform in Kenya Country. Oxford University Press. Nairobi.

Temu, A. J. 1972. A War and Society in Africa: The Giriama War 1914-1915. Frank Cass \& Co., Ltd. London.

Tignor, R. L. 出版年不明, The Trensformation of Kenya. London.

Wachanga, H. K. 1975. Sword of Kirinyaga: The Fighter for Land and Freedom. East Africa Literature Bureau. Kampala.

Wolff, R. D. 出版年不明, The Economics and Colonialism Britain and Kenya 1970-1930. 出版社不明, London.

\section{Mau Mau 関係文献}

\section{（1980 年現在著者作成）}

(1) Leakey, L.S. B. 1952. Маи Mau and the Kikuyu. Methuen, London.

(2) Bewes, T. F. G. 1953. Kikuyu Conflict: Mau Mau and the Christian Witness. Highway Press. London.

(3) Colin, W. 1953. Who killed Kenya. Dobson. London.

(4) Stoneham, C. T. 1953. Маи Маи. Museum Press. London.

(5) Carothers, J. C. 1954. The psychology of Maи Mau. Government Print. Nairobi.

(6) Leakey, L. S. B. 1954. Defeating Mau Mau. Methuen. London.

(7) Wison, C. J. 1954. Kenya's Warning: the challenge to white supremacy in our British Colony. Nairobi English Press. Nairobi.

(8) Leigh, L. 1955. In the shadow of Mau Mau. W. H. Allen. London.

(9) Montgomery, C. E. 1955. The guard village. Voice of Kenya. Nairobi.

(10) Ruark, R. C. 1955. Something of Value. Hamilton. London.

(11) Lavers, A. 1955. The Kikuyu who first Mau Mau. Eagle Press. Nairobi.

(12) Henderson, I. 1958. The hunt for Kimathi. Hamilton. London. 
(13) 1958. Man hunt in Kenya. N.Y. Doubleday. Garden City.

(14) Colonial Office 1959. Documents relating to the death of eleven Mau Mau detainee at Hola Camp in Kenya. Parliament paper by Command Government Print. London.

(15) 1959. Further document relating to the death of eleven Mau Mau detainees at Hola Camp in Kenya. Government Print. London.

(16) Colonial Office 1959. Record of proceeding and evidence in the inquiry into the death of eleven Mau Mau detainees at Hola Camp in Kenya. Government Print. London.

(17) Corfield, F. D. 1960. The Origins and Growth of Mau Mau. Kenya Colony and Protectorate, Legialative Council Sessional paper No. 5 of 1959-1960. Government Print. Nairobi.

(18) A publication of the Makerere Kikuyu, Embu and Meru Student Association. 1960. Around Mt. Kenya: coment on Corfield.

(19) Kiston, F. 1960. Gans and Counter Gans. Barrie \& Rockliff. London.

(20) Majdalany, F. 1962. State of Emergency: Full story of Маи Маи. Longmans. London.

(21) Kariuki, J. M. 1963. Mau Mau detainee. Oxford University Press. London.

(22) Sorrenson, M. 1963. Counter revolution to Mau Mau: Land consolidation in Kikuyu land 1952-1960. Kampala.

(23) Frey, V. 1964. Cloud over Kenya. Collins. London.

(24) Barnett, D. L. 1966. Mau Mau form within: autobiography and analysis of Kenya's peasant revolt. New York Monthly Review Press. New York.

(25) Rosberg, C. G. \& Nottingham, J. 1966. The Myth of Mau Mau: Nationalism in Kenya. East Africa Publishing House Nairobi.

(26) Itote, W. 1967. Mau Mau General (General China). East Africa Publishing House. Nairobi.

(27) Sorrenson, M. P. K. 1967. Land Reform in Kikuyu Country. Oxford University Press. London.

(28) Kagonbe, M. 1969. Kikuyu Studies: a case of conflict and violence. Paper presented at the Annual Meeting of the African Studies Association. Nairobi.

(29) Onyango-Abuye, J. C. 1970. Mau Mau: A nationalist movement. Makerere University (Graduating research). Nairobi.

(30) Ladislav, V. 1970. A history of Mau Mau movement in Kenya. Charles University. Prague.

(31) Buitenhuijs, R. 1971. Le mouvement "Mau Mau' : Une revolte paysanne et anti-coloniale en Afrigue noire. La Haye. Monton.

(32) Muriithi, J. K. 1971. War in the forest: the personal story of J. K. Muriithi as told to P. N. Ndoria. East Africa Publishing House. Nairobi.

(32) Furley, O. W. 1971. The historiograph of Mau Mau. Annual conference of the Historical Association of
Kenya: Paper. Nairobi.

(33) Rodney, W. 1971. A note on Mau Mau onTanganyika Territory. Annual conference of the Historical Association of Kenya: Paper. Nairobi.

(34) Wamweya, W. 1971. Freedom fighter. East Africa Publishing House. Nairobi.

(35) Historical Association of Kenya 1971. Revolt of the Elder: an anatomy of the loyalist crowd in Mau Mau uprising 1952-1956. Historical Association of Kenya. Nairobi.

(36) The African Studies Association 1972. Workers, Trade unions, and he nationalist movement in Kenya. Paper presented to the Annual Meeting of the African Studies Association. Philadelphia.

(37) Gretha, K. 1972. The land is the people: a study of Kikuyu Social Organization in historical perspective. Chicago University. Chicago.

(38) Wangombe, M. T. 1973. The racial factor as key to the emergency in Kenya. Paper presented in Annual Conference of the Historical Association of Kenya. Nairobi.

(39) Buitenhuijs, R. 1973. Mau Mau: Twenty years after: The myth and the Survivors. The Hague. Monton.

(40) Pickering, Elisa 1975. When the windows were opened: Life on a Kenya farm. G. Bles. London.

(41) Wachanga, H. K. 1975. The Sword of Kirinyaga: the fighter for Land and Freedom. East Africa Literature Bureau. Kampala.

(42) Thiong'o, N. \& Mugo, M. G. 1976. The Trial of Dedan Kimathi. Heineman Education Books. Nairobi.

(43) Maina, P. 1977. Six Mau Mau Generals. Gazelle Books Co., Ltd. Nairobi.

(44) Clayton, A. 1976. Counter-insurgency in Kenya: A Study of military operation against Maи Mau. Transafrica Publishers. Nairobi.

(45) Jwando, O. 1973. White Highland no more. Pan Africa researchers. Nairobi.

(46) Barnett, D. L. 出版年不明, Mau Mau: the structual integration and disintegration of Aberdare guerillaforces. Ann Arbor University Microfilm.

(47) Baxter, E. J. 1954. Mau Mau: the terror that has come to Kenya and what it means. East Africa News Review. Nairobi.

(48) Beecher, L. J. 出版年不明, Christian counter-revolution to Mau Mau. In Rhodesia and East Africa: Joelson, F. S. London.

(49) Voice of Kenya 1954. Emergency in Kenya. Voice of Kenya Print. Nairobi.

(50) Voice of Kenya 1954. The Kikuyu tribe and Mau Mau. Voice of Kenya Print. Nairobi.

(51) Gachukia, E. W. 出版年不明, The Mau Mau War and East africa Creative writing with particular reference to James Ngugi. Nairobi University. Nairobi.

(52) Singh, M. 1969. History of Kenya's Trade Union Movement to 1952. East Africa Publishing House. Nairobi. 